\title{
¿De dónde vienen? Aprovisionamiento de rocas sedimentarias silíceas en el yacimiento magdaleniense al aire libre de Montlleó (Prats i Sansor, Lleida)
}

\author{
Where are they coming from? Procurement of siliceous sedimentary rocks \\ in the Magdalenian open-air site of Montlleó (Prats $i$ Sansor, Lleida)
}

\author{
Marta Sánchez de la Torre ${ }^{a}$ y Xavier Mangado Llach ${ }^{b}$
}

\section{RESUMEN}

En este artículo se presentan los resultados obtenidos tras la caracterización arqueopetrológica de los materiales líticos del yacimiento al aire libre de Montlleó (Prats i Sansor, Lleida). El estudio desarrolla una observación macroscópica, microscópica y geoquímica para conocer las características texturales, petrográficas y micropaleontológicas, así como la composición mineralógica de los tipos de sílex explotados. Los resultados de este trabajo confirman que el yacimiento de Montlleó fue una encrucijada de caminos transitados reiteradamente al fin del Paleolítico superior, evidenciando la inexistencia de barreras geográficas que imposibilitaran la movilidad entre ambas vertientes del área pirenaica centro-oriental.

\begin{abstract}
Results obtained after the archaeopetrological analyses of lithic tools from the open-air site of Montlleo (Prats i Sansor, Lleida) are presented below. Macroscopic, microscopic and geochemical observation permitted recognitionof the textural, petrographic, micropaleontological, as well as mineralogical composition of the exploited cherts. Results confirm that Montlleó was placed at a crossroad area used repeatedly at the end of the Upper Palaeolithic. These results show that geographical barriers did not impede human mobility between both Pyrenean slopes.
\end{abstract}

Palabras clave: Sílex; Aprovisionamiento de materias primas líticas; Patrones de movilidad; Magdaleniense inferior; Pirineo centro-oriental; Península ibérica; Pleistoceno.

Keywords: Chert; Lithic raw material procurement; Mobility patterns; Lower Magdalenian; Central-Eastern Pyrenees; Iberian Peninsula; Pleistocene.

\section{INTRODUCCIÓN}

El estudio de las materias primas líticas desde la disciplina arqueopetrológica es indispensable si se pretende conocer mejor a los grupos humanos que las emplearon. Esta analítica investiga las características petrológicas de los elementos líticos recuperados en los yacimientos arqueológicos y las intenta identificar en las eventuales formaciones geológicas de procedencia. Además, al concebir el útil como elemento portador de una información de carácter natural y cultural, define los rasgos culturales implícitos en la gestión de dichos recursos.

En las últimas décadas venimos asistiendo a un importante desarrollo de la disciplina arqueopetrológica a escala cuantitativa, con el incremento de este tipo de estudios, y cualitativa al innovarse las técnicas de caracterización físico-química de

a,b Seminari d'Estudis i Recerques Prehistòriques (SERP), Facultat de Geografia i Història. Universitat de Barcelona (UB). 08001 Barcelona.

Correos e.: martasanchezdelatorre@ub.edu; mangado@ub.edu

Recibido 13-II-2015; aceptado 2-XI-2015. 
los materiales líticos (Bressy 2003; Tarriño 2006). Así, cada vez son más habituales las caracterizaciones de la composición mineralógica de los sílex por Difracción de Rayos X (Roy et al. 2013; Soto et al. 2014) o de composición elemental por Fluorescencia de Rayos X (Gauthier et al. 2012), por Espectrometría de Masas por Plasma Acoplado Inductivamente (Speer 2014) o por Espectroscopía de Infrarojos por Transformada de Fourier (Olivares et al. 2009; Hassler et al. 2013; Parish et al. 2013).

En la Península Ibérica, y en concreto en el Pirineo y Prepirineo centro-oriental, el descubrimiento reciente de yacimientos arqueológicos acrecienta este auge del análisis de las materias primas líticas. La excavación de nuevos asentamientos ha documentado una ocupación humana de este área montañosa al menos desde el Paleolítico medio (Mangado et al. 2010; Utrilla et al. 2010). Al sur del Prepirineo oriental a los descubrimientos del Magdaleniense de fines del siglo XIX y principios del XX en la Bora Gran d'en Carreres (Serinyà, Girona) (Soler 1976), en los últimos decenios se han sumado otros en yacimientos del sector oscense y leridano con características y dataciones atribuidas a diferentes fases de ese periodo cronocultural (Mangado et al. 2010; Utrilla et al. 2010; Fullola et al. 2012) (Fig. 1). Al primer sector corresponden los hallazgos de la cueva de Chaves (Bastarás) (Utrilla et al. 2010), la Fuente del Trucho (Asque-Colungo) (Utrilla et al. 2014), el Abrigo de Forcas I (Graus) (Utrilla y Mazo 2014) y la Cova Alonsé (Estadilla) (Montes y Domingo 2013) y al Prepirineo leridano los de la Cova del Parco (Alòs de Balaguer) (Mangado et al. 2014) y Cova Gran (Santa Linya) (Mora et al. 2014). Completa este conjunto el yacimiento al aire libre de Montlleó (Prats i Sansor, Lleida) (Mangado et al. 2015), ubicado en pleno Pirineo centro-oriental.

El hallazgo y datación de estas ocupaciones magdalenienses a lo largo del Pirineo y Prepirineo centro-oriental es un importante marcador territorial y temporal que indica la existencia de un territorio frecuentado al fin del Paleolítico superior. El análisis de las materias primas líticas se entrevé como una importante herramienta para conocer mejor el tipo de frecuentación del territorio y la relación de estos grupos humanos con su entorno.

Nuestra voluntad en este artículo es dar a conocer los resultados del estudio arqueopetro- lógico efectuado en el yacimiento magdaleniense al aire libre de Montlleó (Prats i Sansor, Lleida). La caracterización macroscópica, microscópica y geoquímica obtenida permite definir la ocupación de Montlleó como una encrucijada de caminos de ocupación reiterada al fin del $\mathrm{Pa}$ leolítico superior.

\section{EL YACIMIENTO MAGDALENIENSE DE MONTLLEÓ}

\subsection{Contexto geológico y geográfico}

El yacimiento al aire libre de Montlleó está en el término municipal de Prats i Sansor, en la comarca de la Cerdaña, en el límite nordeste de la provincia de Lleida. Se sitúa a 1.134 metros s.n.m., en el lugar conocido como Coll de Saig, junto a la carretera que desde Bellver de Cerdaña lleva a Prats, y a unos $250 \mathrm{~m}$ de distancia del río Segre. El asentamiento se localiza alrededor de un pequeño afloramiento de conglomerados de edad postmiocena, probablemente Villafranquiense. El valle de la Cerdaña donde se ubica es una depresión orientada NE-SO en la parte oriental de la zona axial pirenaica. El valle tiene como peculiaridad una estructura dividida en dos unidades morfológicas: la montaña y el llano. Está rodeado por una red de macizos montañosos del Paleozoico. Entre sus cimas destacan el Puigpedrós, la Tossa o el Carlit, éste último con $2.921 \mathrm{~m}$. Por la gran explanada de origen cuaternario y con una suave inclinación en dirección E-O discurre algo más de $40 \mathrm{~km}$ el río Segre que nace entre las cimas del Puigmal y Finestrelles (Fig. 1).

\subsection{Excavación}

El Sr. Jordi Grimao, aficionado a la arqueología y gran conocedor del lugar, descubrió en 1998 el yacimiento de Montlleó tras exhaustivos trabajos de prospección. Gracias a ellos observó restos líticos y faunísticos in situ que afloraban en un corte erosivo del terreno provocado por movimientos recientes de desestabilización de la vertiente. Estos movimientos se relacionaban con la explotación a cielo abierto de una mina

Trab. Prehist., 73, N. ${ }^{\circ}$ 1, enero-junio 2016, pp. 7-28, ISSN: 0082-5638

doi: $10.3989 /$ tp.2016.12161 

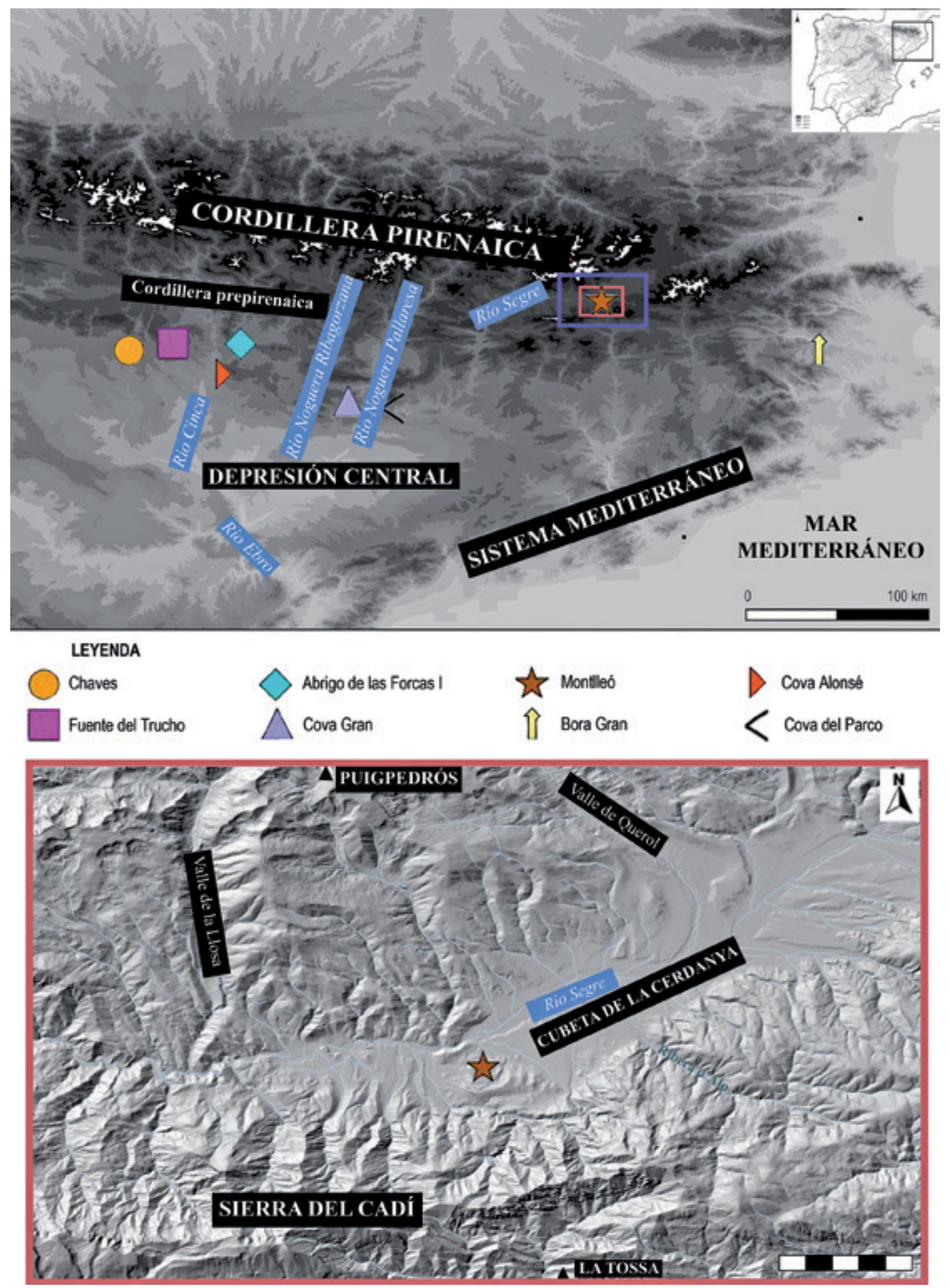

Fig. 1. Localización del yacimiento de Montlleó (Prats i Sansor, Lleida) y principales accidentes geográficos y geológicos del entorno. Fuente: Instituto Geográfico Nacional, MDT 1:200.000 e Institut Cartogràfic de Catalunya, MDT 1:25.000, modificada. 
de lignito que estuvo en funcionamiento en las inmediaciones del sitio hasta finales de la década de los ochenta. La posterior remoción de tierras, orientada a reducir el impacto visual de la mina sobre el paisaje, puso en peligro la integridad del yacimiento.

El Sr. Grimao comunicó el hallazgo al director del Museo Ceretano de Puigcerdà, quien contactó con el Seminari d'Estudis i Recerques Prehistòriques (SERP) de la Universidad de Barcelona. La primera impresión fue que se trataba de un yacimiento de cronología paleolítica, tanto por las características tecnotipológicas del material lítico, como por la fauna asociada. La recuperación en el mismo corte estratigráfico de un molar de Equus caballus proporcionó una primera datación del yacimiento, previa a cualquier intervención (OxA9017:15440 $\pm 80 \mathrm{BP} / \mathrm{CalPal}: 18650 \pm 50 \mathrm{Cal} \mathrm{BP} /$ $16700 \pm 50$ cal BC) (Mangado et al. 2011). Tras diversas campañas de excavación arqueológica en el mismo, se han recuperado otros vestigios también datados por radiocarbono (Tab. 1).

Los trabajos arqueológicos en el yacimiento comenzaron en 2000, y se han sucedido anualmente hasta 2013. Desde su inicio se establecieron los sectores de excavación $\mathrm{A}, \mathrm{B}$ y $\mathrm{C}$ a 10 largo del corte estratigráfico donde se localizó el yacimiento (Fig. 2), destacando especialmente el material arqueológico proporcionado por los dos últimos. En el sector B las intervenciones arqueológicas han sido continuas. Se han excavado $38 \mathrm{~m}^{2}$ que han aportado el material arqueológico más numeroso. El nivel I, documentado en todo el sector, posee una potencia variable, adaptada a la pendiente natural del yacimiento (NE-SO). Se caracteriza por un sedimento de coloración marrón oscura relativamente blando, que forma agregados con gravas y gravillas de morfologías diversas y algún bloque. Es arqueológicamente fértil. Bajo este horizonte se halla el nivel II, con un sedimento muy fino y duro con presencia de

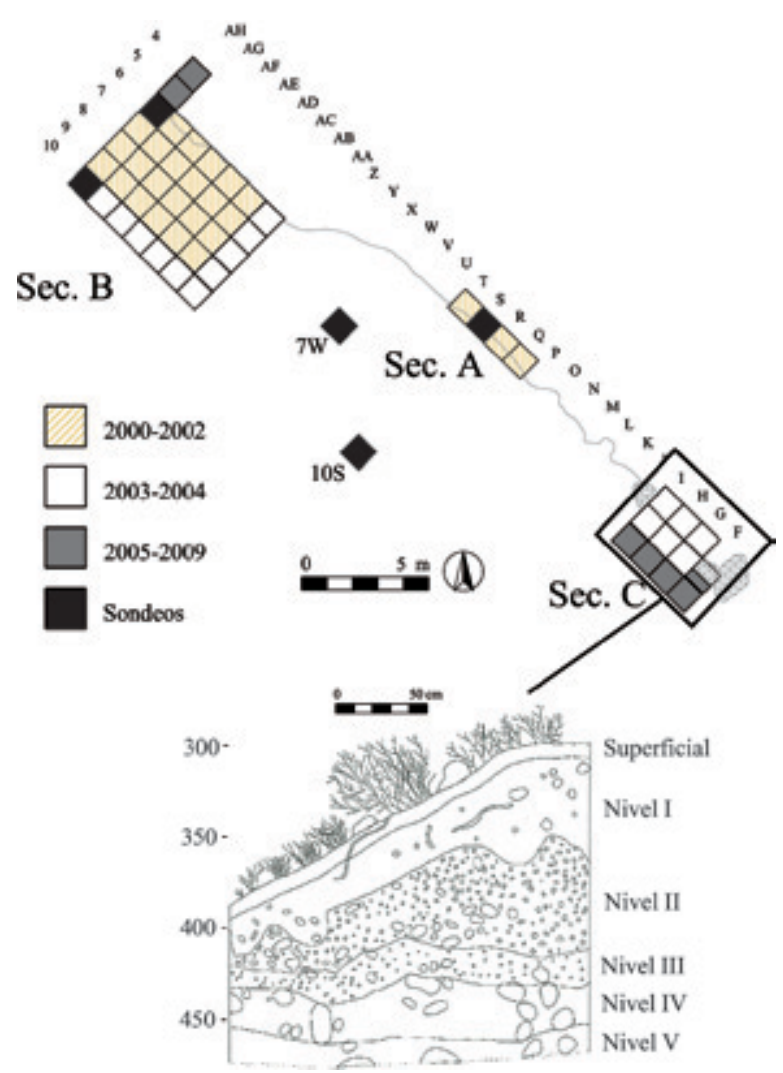

Fig. 2. Planta del yacimiento de Montlleó con los tres sectores abiertos, los cuadros excavados y la estratigrafía del sector C (según Mangado et al. 2014, modificado).

precipitación de nódulos de carbonato cálcico. Es arqueológicamente estéril como ha confirmado un sondeo en profundidad.

El sector $C$ fue intervenido por primera vez en 2003, tras la caída natural de un gran bloque de conglomerado que dejó al descubierto una superficie de excavación de $6 \mathrm{~m}^{2}$, posteriormente ampliada a $11 \mathrm{~m}^{2}$ y una secuencia estratigráfica en el perfil norte de los cuadros 4H y 4I de unos

\begin{tabular}{|c|c|c|c|c|c|}
\hline Referencia & Material datado & Sector & Datación BP & Cal BP & Cal BC \\
\hline OxA-9017 & Molar de caballo & B & $14440 \pm 80$ & $18650 \pm 50$ & $16700 \pm 50$ \\
\hline OxA-14034 & Carbón & C & $15550 \pm 140$ & $18710 \pm 80$ & $16760 \pm 80$ \\
\hline OxA-X2234-52 & Molar de caballo & B & $16900 \pm 110$ & $20320 \pm 120$ & $18370 \pm 120$ \\
\hline
\end{tabular}

Tab. 1. Dataciones radiocarbónicas de Montlleó con su calibración. Según Mangado et al. (2011: 29).

Trab. Prehist., 73, N.o ${ }^{\circ}$, enero-junio 2016, pp. 7-28, ISSN: 0082-5638

doi: $10.3989 /$ tp.2016.12161 
$175 \mathrm{~cm}$ (Fig. 2). Su análisis sedimentario y micromorfológico identificó 5 niveles sedimentarios (Mangado et al. 2011: 37).

\section{METODOLOGÍA DE ESTUDIO}

El presente estudio emplea la metodología de análisis de la Arqueopetrología, que recurre a las descripciones y nomenclaturas propias de las Ciencias de la Tierra, como la Petrología, para caracterizar, definir y denominar las rocas utilizadas por las sociedades del pasado. La caracterización del material lítico ha combinado dos análisis sucesivos a diferentes escalas: el macroscópico y el petrográfico. Con el primero, el nivel básico de observación, se ha examinado todo el conjunto retocado y una muestra aleatoria de restos de talla. Se han definido una serie de subgrupos en función del contenido micropaleontológico y de inclusiones, específicos de cada medio de sedimentación. En el estudio se ha utilizado una lupa binocular modelo OLYMPUS SZ61 (de 6.7 a 45 aumentos) y una fuente de iluminación complementaria, en función de las muestras de sílex, de luz fría transmitida modelo OLYMPUS TH4-200. Las instantáneas se han efectuado con una cámara fotográfica acoplada modelo OLYMPUS SC30.

La caracterización petrográfica y micropaleontológica de los materiales, al tratarse de una técnica destructiva, se ha efectuado sobre una selección de piezas del conjunto no retocado estudiado macroscópicamente. Las láminas delgadas (de entre 25 y $30 \mu \mathrm{m}$ ) han sido elaboradas en el Servei de Làmina Prima de la Universidad de Barcelona y analizadas con un microscopio petrográfico modelo OLYMPUS BX41 (de 40 a 400 aumentos). Las instantáneas de los elementos descritos se han tomado con una cámara fotográfica acoplada modelo OLYMPUS SC30.

En paralelo se ha contextualizado geográfica y geológicamente el área de estudio para localizar las formaciones donde afloran las materias primas explotadas en el yacimiento. Los depósitos secundarios pudieron ser los más frecuentados por los grupos de cazadores-recolectores de la Prehistoria pero los afloramientos primarios donde el sílex está en su lugar de formación original permiten observarlo in situ. Para la consulta cartográfica inicial se han utilizando las hojas disponibles de la serie Magna del Instituto Geológico y Minero de España (en adelante IGME) (a escala 1:50.000) (IGME 1994, 1995, 1998, 2005), así como el Atles Geològic de Catalunya (2010), a escala 1:50.000 y las hojas disponibles a 1:25.000 del Institut Geològic de Catalunya y del Institut Cartogràfic de Catalunya (ICC 2008). Una vez definidas sobre un mapa las áreas potencialmente portadoras de sílex, se salió al campo para documentar y muestrear los depósitos. Se ha elaborado una caracterización precisa (que incluye láminas delgadas) de las muestras geológicas recuperadas en las tareas de prospección, destinada a compararlas con las muestras arqueológicas. Los resultados permiten interpretaciones de carácter arqueológico relativas al aprovisionamiento y gestión de las materias primas líticas por parte de los grupos humanos que ocuparon el yacimiento al aire libre de Montlleó. Además, la consulta de la Lithothèque de Roches siliceuses del laboratorio TRACES de la Universidad de Toulouse - Jean Jaurès nos permitió conocer las características de los principales tipos de sílex que afloran en la vertiente norte del Pirineo.

Posteriormente se ha realizado una primera caracterización de la composición mineralógica de las variedades de sílex identificadas, así como de las formaciones susceptibles de haber sido explotadas, mediante Difracción de Rayos X. Los análisis se han llevado a cabo en el Laboratorio de Arqueometría del Centro Nacional de Investigación sobre la Evolución Humana (CENIEH) en Burgos. Se ha utilizado un difractómetro PANalytical X'Pert PRO con geometría BraggBrentano en configuración $\theta-\theta$, porta-muestras de carga trasera, radiación de $\mathrm{Cu}-\mathrm{K} \alpha(1.541874 \AA)$ y rendija de divergencia variable, rendija antiscatter de 7,5 mm. Las muestras geológicas y arqueológicas se han sometido a las mismas condiciones analíticas (Step de $0,02^{\circ}$, rango de $2 \theta$ de $10^{\circ}-75^{\circ}$, excitación a $45 \mathrm{kV}$, y $40 \mathrm{~mA}$ ). En los análisis semi-cuantitativos se ha seguido el método Chung (1974). 


\section{RESULTADOS}

\subsection{Características del conjunto. Definición de tipos de sílex}

La industria lítica del yacimiento de Montlleó recuperada en las campañas del 2000 al 2012, ambas incluidas, tiene 19.901 elementos. De ese total se excluyen los ejemplares procedentes de caídas de corte, recogidas generales y niveles superficiales. Más de 13.000 son rocas sedimentarias silíceas $^{1}$ (13.323), que representan un $66,95 \%$ de la industria. No obstante, muchas otras litologías fueron empleadas para la elaboración del utillaje lítico (Tab. 2).

\begin{tabular}{|l|r|r|}
\hline \multicolumn{1}{|c|}{ LITOLOGÍA } & \multicolumn{1}{c|}{$\mathbf{N}^{\mathbf{o}}$} & \multicolumn{1}{c|}{$\%$} \\
\hline Sílex & 12.430 & $62,46 \%$ \\
\hline Jaspe & 36 & $0,18 \%$ \\
\hline Calcedonia & 1 & $0,01 \%$ \\
\hline Caliza & 44 & $0,22 \%$ \\
\hline Caliza silicificada & 2 & $0,01 \%$ \\
\hline Cuarzo & 2.939 & $14,77 \%$ \\
\hline Lidita & 838 & $4,21 \%$ \\
\hline Cristal de roca & 508 & $2,55 \%$ \\
\hline Riolita & 2.172 & $10,91 \%$ \\
\hline Arenisca & 7 & $0,04 \%$ \\
\hline Cornubianita & 32 & $0,16 \%$ \\
\hline Cuarcita & 317 & $1,59 \%$ \\
\hline Esquisto & 466 & $2,34 \%$ \\
\hline Filita & 3 & $0,02 \%$ \\
\hline Granito & 28 & $0,14 \%$ \\
\hline Pizarra & 33 & $0,16 \%$ \\
\hline Pórfido & 3 & $0,02 \%$ \\
\hline Roca metamórfica & 26 & $0,13 \%$ \\
\hline Silicificación de contacto & 16 & $0,08 \%$ \\
\hline TOTAL GENERAL & 19.901 & $100,00 \%$ \\
\hline
\end{tabular}

Tab. 2. Litologías explotadas en el yacimiento de Montlleó.

\footnotetext{
${ }^{1}$ Se incluyen sílex, jaspes, calcedonias, liditas, calizas silicificadas y silicificaciones de contacto
}

De los 19.901 elementos que configuran la industria lítica, un total de 1.777 piezas son tipos primarios según la tipología Laplace (1974), lo que supone un $8,93 \%$ del total ${ }^{2}$. El sílex es la materia prima principal (1.197 - 79,06\%), seguido por la riolita (209-3,80\%), el cuarzo (34-2,25\%), la lidita $(23-1,52 \%)$, la cuarcita $(18-1,19 \%)$, el jaspe $(14-0,92 \%)$, el cristal de roca $(11-0,73 \%)$, la silicificación de contacto (4 - 0,26\%), la caliza (3-0,20\%) y la roca metamórfica $(1-0,07 \%)$.

En la cubeta neógena de la Cerdaña no aflora sílex en posición primaria o subprimaria y las prospecciones han evidenciado que tampoco lo hace en posición secundaria. Las formaciones con sílex más cercanas al yacimiento se han localizado al otro lado de la sierra del Cadí (Formación Corones), a escasos $10 \mathrm{~km}$ al sur de Montlleó. Son sílex estratificados y nodulares altamente tectonizados y cuya aptitud de talla consideramos mediocre. En las cumbres situadas al norte de la Cerdaña afloran liditas estratificadas, también fuertemente tectonizadas, en niveles del Silúrico (IGME 1995). Debido al importante uso de las rocas no sedimentarias silíceas por los grupos de cazadores-recolectores en el yacimiento, hemos creído indispensable dedicar algunas líneas a estas litologías.

El sílex está ausente en los alrededores del yacimiento, pero el resto de las litologías explotadas en Montlleó son muy habituales en depósitos primarios o secundarios (coluviones, aluviones...). En las proximidades del Coll del Pendís, a pocos $\mathrm{km}$ al SO del yacimiento, ha sido localizado un afloramiento de riolitas del Pérmico cuyas características a escala macroscópica son idénticas a las de las halladas en los niveles arqueológicos de Montlleó. Además, en las cercanías del yacimiento afloran filones de cuarzo y de pórfido y granitos, todos ellos del Carbonífero, cuarcitas y pizarras del Ordovícico, y formaciones con areniscas, calizas, esquistos y filitas, entre otros. Así, aún a falta de análisis precisos, podemos intuir un origen local, próximo al yacimiento, para estas rocas distintas de las sedimentarias silíceas. Confirmar esta hipótesis requiere manejar la geoquímica en una escala de análisis más precisa (mineralógica y de composición elemental) que corrobore las

\footnotetext{
2 Quedan fuera de este artículo 263 elementos en estudio traceológico por el Dr. Manuel Calvo de la Universitat de les Illes Balears (UIB).
}

Trab. Prehist., 73, N. ${ }^{\circ}$ 1, enero-junio 2016, pp. 7-28, ISSN: 0082-5638

doi: $10.3989 /$ tp.2016.12161 


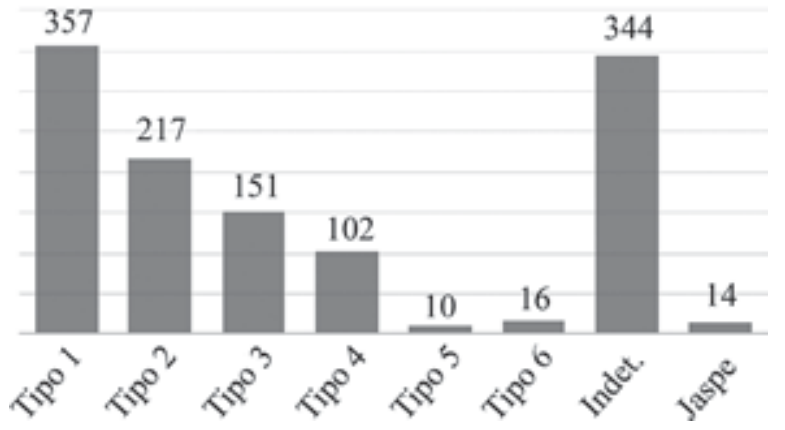

Fig. 3. Total de piezas de sílex en función de los tipos de sílex diferenciados en Montlleó.

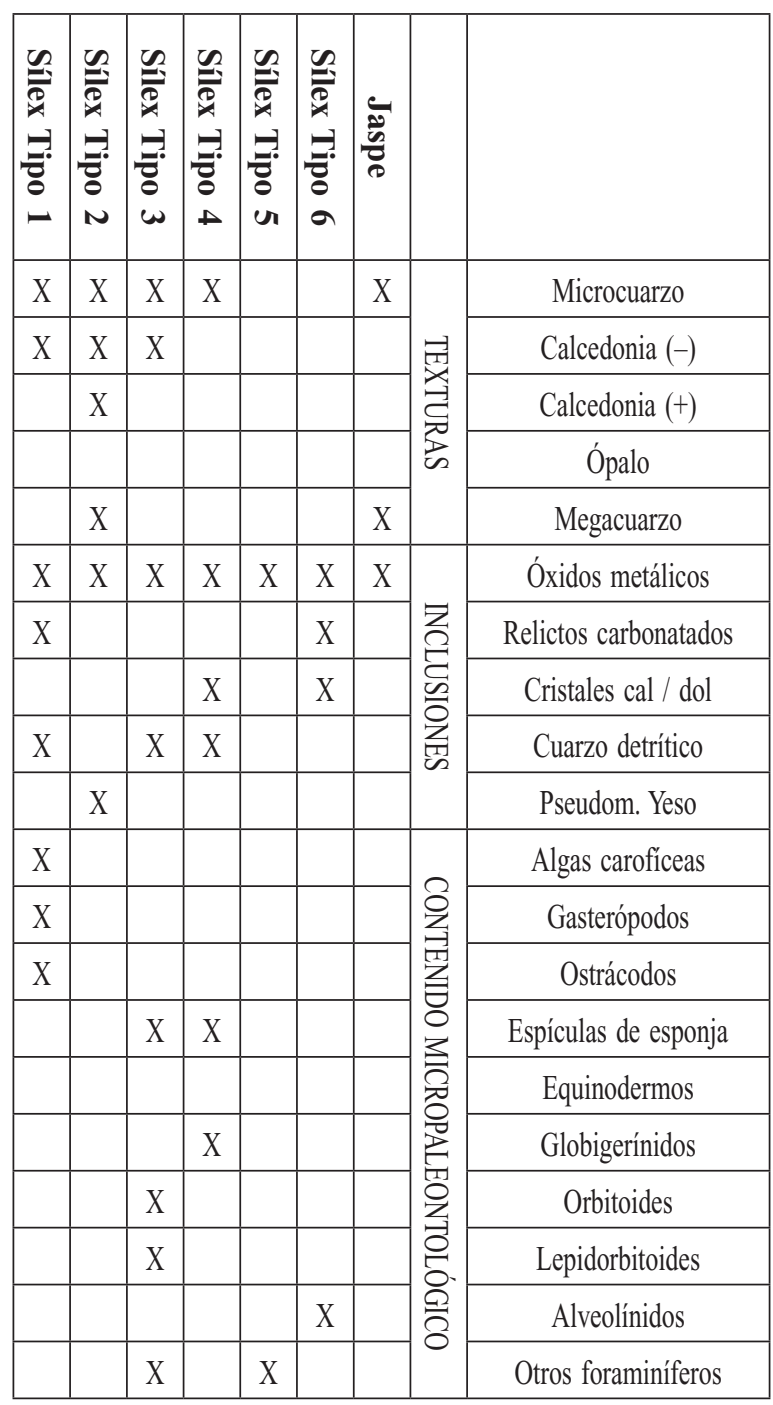

Tab. 3. Cuadro resumen con las principales características de las variedades silíceas analizadas en Montlleó. similitudes entre las formaciones geológicas y las evidencias arqueológicas.

Como ya comentamos, el sílex, pese a no hallarse de manera natural en los alrededores inmediatos del yacimiento, fue el material más utilizado para la confección del utillaje retocado. Su estudio nos ha permitido diferenciar seis tipos de sílex, además de una variedad jaspeada (Fig. 3, Tab. 3).

\subsubsection{Sílex tipo 1}

Se han adscrito a esta variedad 357 elementos del conjunto de núcleos y útiles retocados $(29,83 \%)$. Este tipo posee una alta aptitud de talla. La coloración oscila entre el marrón y el marrón muy oscuro. El córtex, cuando se conserva $(17,37 \%)$, es de litología caliza con tendencia a margosa y con un contacto neto con la masa silícea. La textura heredada es heterogénea con inclusiones abundantes de óxidos y relictos carbonatados. El contenido bioclástico es muy abundante y está representado por secciones de algas carofitas y en menor medida de gasterópodos y ostrácodos (Fig. 4: T.1). En proporciones muy reducidas $(0,84 \%)$ aparecen estructuras anulares (anillos de Liesegang). Podemos definir estos sílex por sus características como procedentes de una facies sedimentaria de tipo continental lacustre.

A escala microscópica este tipo de sílex posee un mosaico de microcriptocuarzo como textura principal. En proporciones muy inferiores se identifican otras formas de la sílice (calcedonia de elongación negativa y morfología esferulítica y botroidal). Los componentes no silíceos son cuantiosos, siendo los más abundantes los carbonatados, previos a la silicificación, no esqueléticos (micrita) y esqueléticos (secciones de algas carofitas, gasterópodos y ostrácodos en proceso de silicificación). Las paredes de algunos de estos componentes esqueléticos han sido micritizadas (Fig. 5: T.1). Los óxidos metálicos poseen morfología granular y se disponen zonalmente y los componentes terrígenos en forma de gránulos subangulosos de cuarzo detrítico aparecen de modo testimonial. No se observan porosidades.

Las formaciones geológicas con sílex de características similares a escala macroscópica y microscópica se sitúan a más de $100 \mathrm{~km}$ del yacimiento, hacia el nordeste y al otro lado de los 


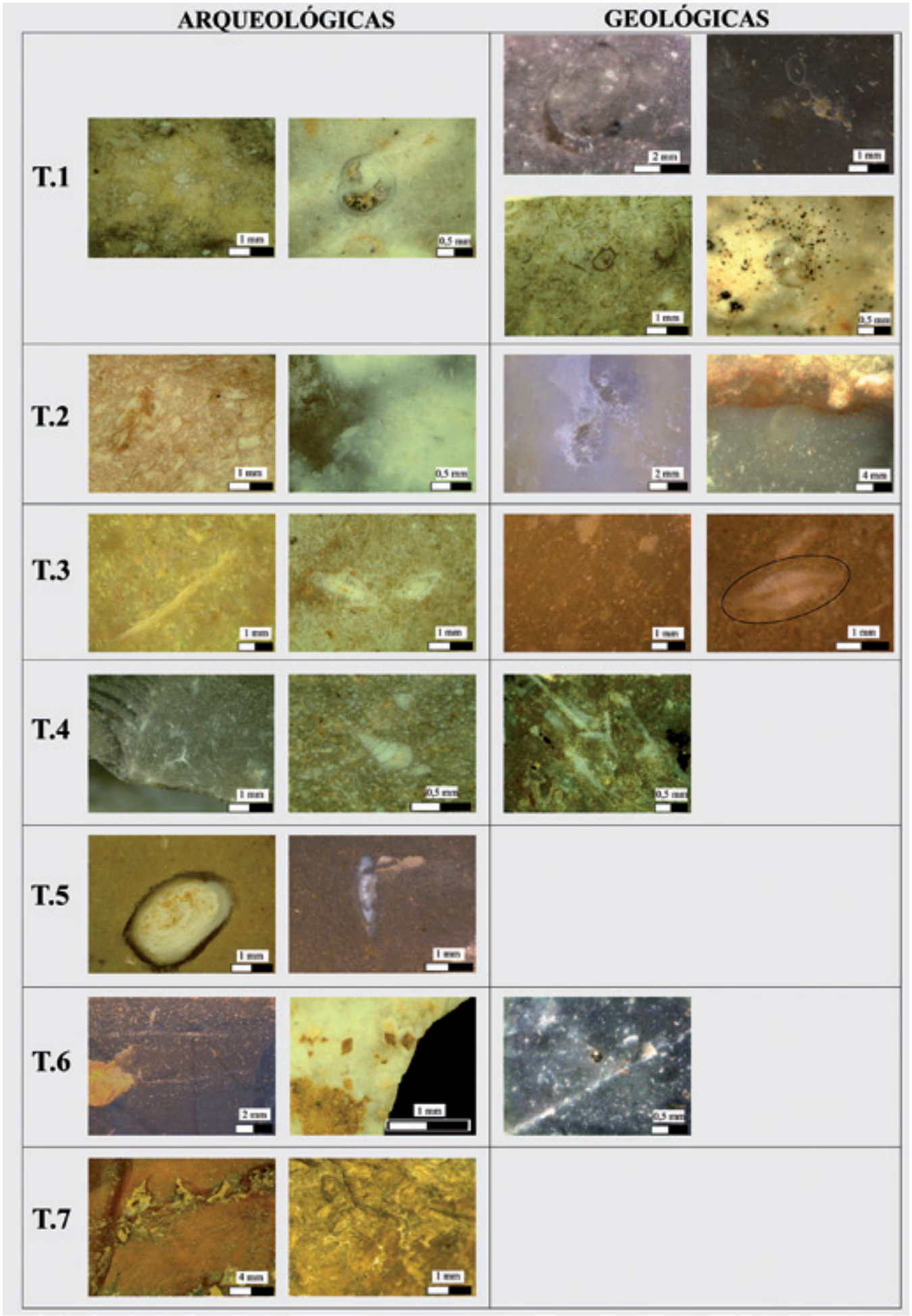

Fig. 4. Imágenes a la lupa binocular de los 7 tipos de sílex identificados en Montlleó. Tipo 1: Algas carofitas (izq.) y gasterópodo (dcha.). Tipo 2: Pseudomorfos lenticulares de yeso. Tipo 3: Posibles Omphalocyclus macroporus (izq.) y Orbitoides (dcha.). Tipo 4: Poríferos (izq.) y textulárido (dcha.). Tipo 5: Alveolínidos. Tipo 6: Textura general (izq.) y cristales romboédricos de calcita o dolomita (dcha.). Tipo 7: Textura general. Publicada en color en la edición electrónica.

Trab. Prehist., 73, N.o ${ }^{\circ}$, enero-junio 2016, pp. 7-28, ISSN: 0082-5638

doi: $10.3989 /$ tp.2016.12161 


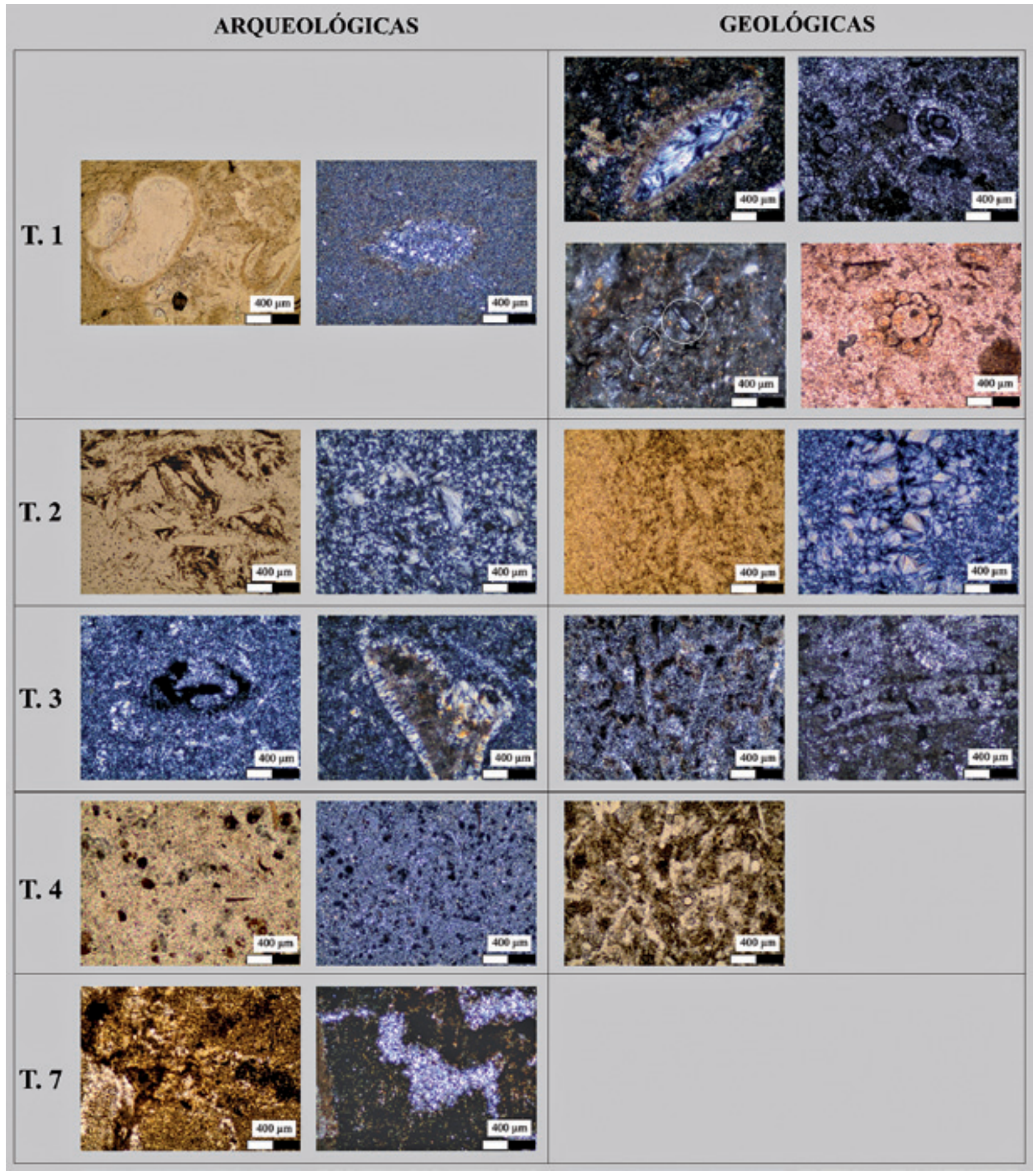

Fig. 5. Imágenes al microscopio petrográfico de 5 de los tipos de sílex identificados en Montlleó. Tipo 1: Gasterópodo en luz paralela (izq.) y alga carofita con pared micritizada e interior silicificado con nícoles cruzados (dcha.). Tipo 2: Pseudomorfos lenticulares de yeso con luz paralela (izq.) y nícoles cruzados (dcha.). Tipo 3: Bioclasto silicificado con nícoles cruzados. Tipo 4: Textura general con inclusiones de óxidos en luz paralela (izq.) y nícoles cruzados (dcha.). Tipo 5: Textura general en luz paralela (izq.) y nícoles cruzados (dcha.). Publicada en color en la edición electrónica. 


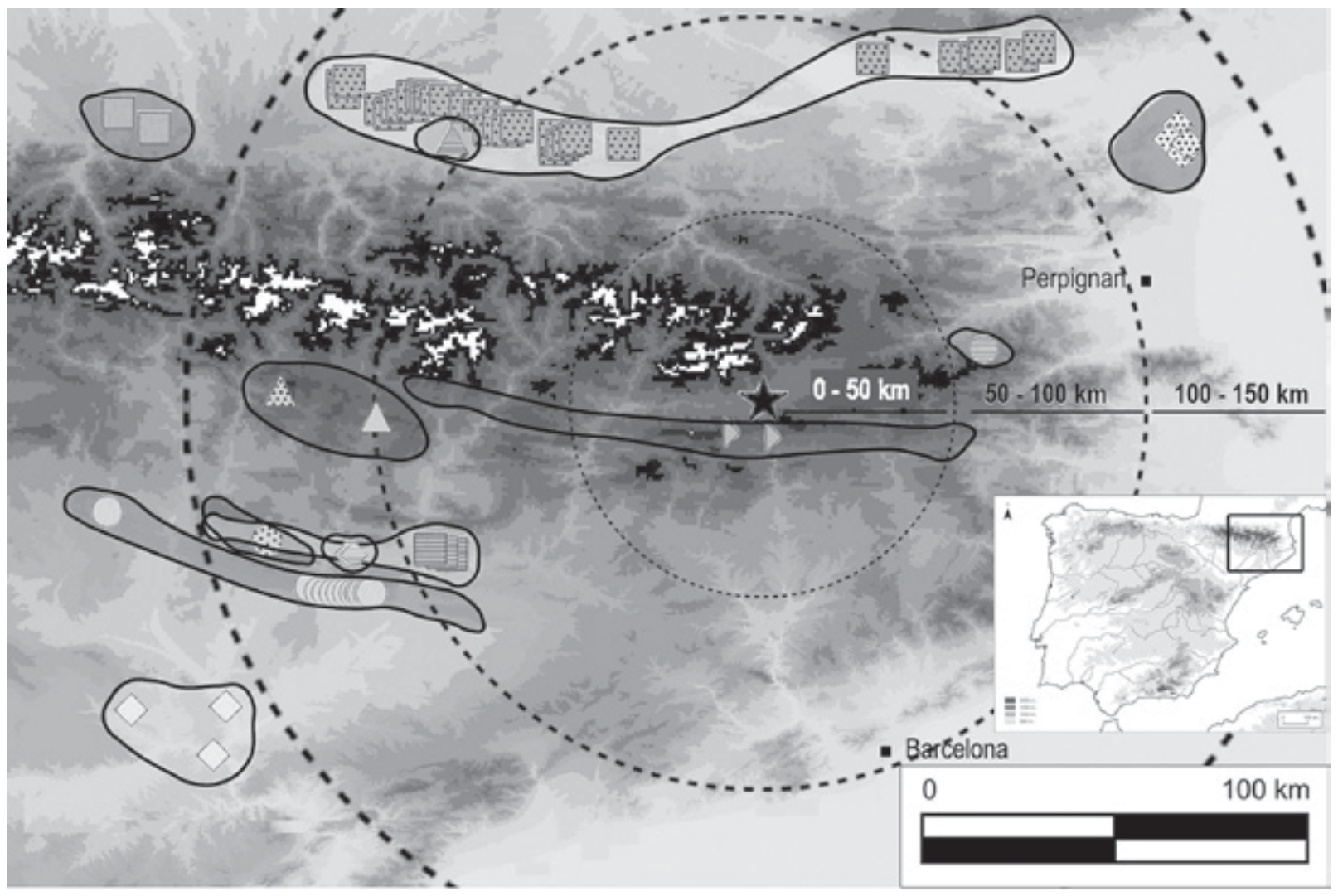

LEYENDA

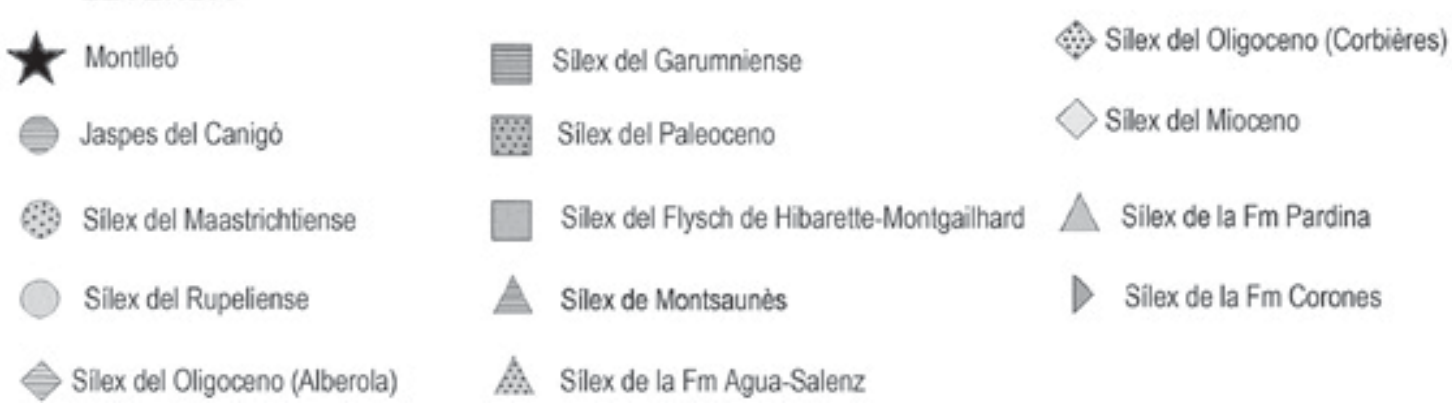

Fig. 6. Ubicación del yacimiento de Montlleó y de las formaciones susceptibles de haber sido explotadas para obtener los principales tipos de sílex identificados en el mismo. Fuente: Instituto Geográfico Nacional, MDT 1:200.000, modificada.

Pirineos (formaciones del Mioceno del macizo de Corbières) (Briois 2005), y en el Prepirineo centrooriental (Roy et al. 2013) -sílex del Maastrichtiense (IGME 1990), Rupeliense (Anadón et al. 1989; Mangado 2005) y Oligoceno (Ullastre y Masriera 1988) - y la Cuenca del Ebro (sílex miocenos) (Gomis et al. 1997), al suroeste de Montlleó (Fig. 6).

En las muestras analizadas por Difracción de Rayos X (Tab. 4) se observa una diversidad entre las formaciones geológicas susceptibles de haber sido explotadas y ningún paralelo directo con la muestra analizada del sílex del tipo 1. La muestra arqueológica presenta un contenido en cuarzo del 99,5\%, con un aporte muy reducido de calcita $(0,5 \%)$. Es un sílex muy puro y con bajo contenido de impurezas. La muestra del macizo de Corbières está constituida por cuarzo (86\%), dolomita $(8 \%)$ y posible moscovita $(6 \%)$. En las 
muestras de la vertiente surpirenaica se observa una cierta diversidad. El sílex del Maastrichtiense posee cuarzo $(94 \%)$, posible moscovita $(5 \%)$ y algo de calcita (1\%). La muestra del Rupeliense tiene cuarzo $(87 \%)$, posible moscovita $(7 \%)$ y calcita $^{3}(6 \%)$. Por último, el sílex oligoceno de Tartareu-Alberola posee el porcentaje más alto en cuarzo (96\%) de las muestras geológicas y un $4 \%$ de calcita.

\begin{tabular}{|lccccc|}
\hline MUESTRA & $\begin{array}{c}\text { ARQ/ } \\
\text { GE0 }\end{array}$ & Sílice & Calcita & Dolomita & Moscovita \\
\hline M0'T1 & Arq. T1 & $99,8 \%$ & $0,2 \%$ & $0 \%$ & $0 \%$ \\
\hline Alberola & Geo. T1 & $96,4 \%$ & $3,6 \%$ & $0 \%$ & $0 \%$ \\
Candasnos & Geo. T1 & $89,7 \%$ & $2,5 \%$ & $0 \%$ & $7,8 \%$ \\
\hline Corbières & Geo. T1 & $86 \%$ & $0 \%$ & $8 \%$ & $6 \%$ \\
Peraltilla & Geo. T1 & $87,4 \%$ & $5,9 \%$ & $0 \%$ & $6,7 \%$ \\
\hline Zurita & Geo. T1 & $94,5 \%$ & $0,3 \%$ & $0 \%$ & $5,2 \%$ \\
M0’'T2 & Arq. T2 & $100 \%$ & $0 \%$ & $0 \%$ & $0 \%$ \\
\hline Alins & Geo. T2 & $89,9 \%$ & $0 \%$ & $0 \%$ & $10,1 \%$ \\
VsSM & Geo. T2 & $96,2 \%$ & $0 \%$ & $0 \%$ & $3,8 \%$ \\
\hline Paleoceno & Geo. T2 & $100 \%$ & $0 \%$ & $0 \%$ & $0 \%$ \\
M0’T3 & Arq. T3 & $99,2 \%$ & $0,8 \%$ & $0 \%$ & $0 \%$ \\
\hline Montgaillard & Geo. T3 & $91,6 \%$ & $0 \%$ & $0 \%$ & $8,4 \%$ \\
Montsaunès & Geo. T3 & $92,7 \%$ & $0 \%$ & $0 \%$ & $7,3 \%$ \\
\hline M0'T4 & Geo. T3 & $96,7 \%$ & $3,3 \%$ & $0 \%$ & $0 \%$ \\
Agua-Salenz & Geo. T3 & $93,6 \%$ & $5,3 \%$ & $1,1 \%$ & $0 \%$ \\
\hline
\end{tabular}

Tab. 4. Datos obtenidos del análisis de DRX de las muestras geológicas y arqueológicas (Montlleó) estudiadas.

A nivel mineralógico el sílex tipo 1 se asemeja más a la muestra del sílex oligoceno de TartareuAlberola. Sin embargo, esta similaridad no es tan acentuada si observamos las láminas delgadas o las descripciones a la lupa binocular. En este momento de la investigación no podemos precisar más el lugar de aprovisionamiento de este tipo

\footnotetext{
3 La aparición de la moscovita en algunos difractogramas, con picos muy cercanos a la zona de ruido, nos lleva a considerar con cautela su presencia en las muestras. Por ese motivo el término posible precede a la moscovita en todos los casos.
}

de sílex y un estudio mineralógico completo, así como de composición elemental, se entrevé necesario para poder aportar nuevos datos.

\subsubsection{Sílex tipo 2}

Comprende 217 elementos del conjunto estudiado $(18,13 \%)$. Es un sílex originado en facies de sedimentación continental lacustre evaporítica y caracterizado por la ausencia de contenido bioclástico. Tiene una aptitud alta para la talla, coloraciones claras y generalmente translúcidos. El córtex, cuando se conserva $(22,58 \%)$, es de litología caliza y escasamente rodado, con un contacto algo difuso con la masa silícea. La textura heredada es bastante homogénea y el contenido en inclusiones muestra óxidos metálicos y pseudomorfos lenticulares de yeso (Fig. 4: T.2). En algunos casos se identifican recristalizaciones de megacuarzo. Al microscopio petrográfico los sílex del tipo 2 tienen características similares con proporciones variables en función de la lámina delgada analizada. La textura principal se compone de un mosaico de microcriptocuarzo. Están presentes otras formas de la sílice como los mosaicos de megacuarzo, que aparecen testimonialmente, y la sílice fibrosa, de elongación tanto negativa como positiva, en ambos casos de morfología esferulítica (Fig. 5: T.2). La observación de ambos tipos de elongación de la calcedonia es un factor indicativo de un cambio en las condiciones de silicificación durante la diagénesis. Los componentes carbonatados en forma de micrita son abundantes en algunas láminas, aunque generalmente están en proporciones muy inferiores. Los óxidos metálicos como gránulos de hematites suelen ser abundantes, así como los testimonios evaporíticos en forma de pseudomorfos lenticulares de yeso (Fig. 5: T.2). En alguna lámina se han detectado porosidades de tipo intergranular.

Las formaciones geológicas con sílex de similares características a las del tipo 2 se hallan a más de $100 \mathrm{~km}$ del yacimiento de Montlleó. En concreto, dos de ellas son susceptibles de haber sido explotadas por los grupos humanos que durante el Magdaleniense se asentaron en el yacimiento (Fig. 6). A algo más de $100 \mathrm{~km}$ al suroeste del mismo, en el Prepirineo centro-oriental, afloran las calizas del Garumniense con sílex (Mangado 
2005; IGME 2006; Roy et al. 2013) con idénticas características a las observadas macroscópica y microscópicamente en el tipo 2. Por otro lado, a algo más de $100 \mathrm{~km}$ al nordeste y noroeste de Montlleó afloran las calizas del Paleoceno con nódulos de sílex (Bleu) (Simonnet 1999) cuyo aspecto a la lupa binocular y al microscopio petrográfico es muy similar al de los sílex del tipo 2 .

La composición mineralógica (Tab. 4) de la muestra analizada del tipo 2 se compone exclusivamente de cuarzo (100\%) siendo un sílex sin impurezas. Si observamos los datos para las dos formaciones susceptibles de haber sido explotadas, notaremos la correlación existente entre el tipo 2 y los sílex Bleu del Paleoceno de la vertiente norpirenaica, también constituidos exclusivamente por cuarzo. Los sílex de la Formación Tremp, en cambio, además de poseer entre un $90 \%$ y un $96 \%$ de cuarzo, contienen posible moscovita (entre 4\% y 10\%). Así, según pone de manifiesto el estudio por Difracción de Rayos X, los sílex del tipo 2 se corresponderían con los sílex del Paleoceno, orientándose de este modo el aprovisionamiento hacia la vertiente norpirenaica.

\subsubsection{Sílex tipo 3}

Se le han atribuido 151 elementos del conjunto de útiles retocados y núcleos (12,61\%). Este tipo de sílex presenta una alta aptitud de talla. El córtex, cuando se conserva $(13,25 \%)$, es de litología caliza y suele aparecer escasamente rodado con un contacto neto con la masa silícea. La coloración general es marrón clara con motas rojizas debido a la alta presencia de óxidos. La textura heredada es heterogénea con abundancia de óxidos y cristales de cuarzo detrítico como principales inclusiones, así como de posibles espículas de esponja (Fig. 4: T.3) y bioclastos, generalmente indeterminados. En determinadas ocasiones se han identificado secciones de grandes foraminíferos como posibles Omphalocyclus macroporus, Orbitoides y Siderolites (Fig. 4). El contenido bioclástico y el tipo de inclusiones presentes en este sílex definen su facies sedimentaria como marina.

Al microscopio petrográfico se observa una textura principal de mosaico de microcriptocuarzo. En proporciones muy reducidas aparece sílice fibrosa de elongación negativa y morfología botroi- dal. Los componentes carbonatados son previos a la silicificación y se observan tanto esqueléticos, con la pared micritizada y el interior en proceso de silicificación, como no esqueléticos (micrita) (Fig. 5: T.3). En proporciones muy escasas aparecen óxidos metálicos granulares y componentes terrígenos (granos de cuarzo detrítico subangulares).

Los sílex adscritos al tipo 3 presentan paralelos con dos formaciones del Cretácico superior que afloran en la vertiente norte del Pirineo central (Fig. 6). Son los sílex del Flysch de Hibarette Montgaillard, datados del Campaniense-Maastrichtiense (Barragué et al. 2001), y los sílex del Maastrichtiense que afloran en las calizas Nankin en las proximidades de Montsaunès (Séronie-Vivien et al. 2006). Ambas silicificaciones comparten abundancia de óxidos, cristales de cuarzo detrítico y espículas silíceas de esponja. Su única diferencia es que los grandes foraminíferos bentónicos clásicos del Maastrichtiense solo se atestiguan en los sílex de Montsaunès (presencia de Lepidorbitoides socialis, Omphalocyclus macroporus, Siderolites y Orbitoides) (Bilotte y Andreu 2006: 311). Todos los sílex adscritos al tipo 3 presentan los caracteres comunes observados en ambas formaciones, pero en determinadas piezas también se han identificado Orbitoides, Siderolites y Omphalocyclus.

El análisis por Difracción de Rayos X del tipo 3 revela una composición mineralógica compuesta principalmente por cuarzo $(99 \%$, calcita $1 \%)$. A nivel mineralógico prácticamente no se observan distinciones entre los sílex de Montgaillard (cuarzo $92 \%$, posible moscovita $8 \%$ ) y Montsaunès (cuarzo 93\%, posible moscovita 7\%) (Tab. 4).

Por todo lo expuesto, a día de hoy proponemos ambas formaciones como susceptibles de haber sido explotadas por los grupos que ocuparon Montlleó para abastecerse de lo que hemos denominado sílex tipo 3. Sabemos que algunas piezas con seguridad proceden del Maastrichtiense de Montsaunès. Las que no presentan macroforaminíferos podrían proceder bien de esta misma formación, bien de la de Hibarette - Montgaillard.

Se trata, por tanto, de un sílex exógeno cuyas fuentes de aprovisionamiento conocidas se sitúan a unos $110 \mathrm{~km}$ en línea recta del yacimiento para los sílex de Montsaunès y a más de $170 \mathrm{~km}$ para los sílex del Flysch de Hibarette -Montgaillard-. La presencia de este tipo de sílex en Montlleó constituye el primer indicador inequívoco de la existencia de contactos con la vertiente norpirenaica.

Trab. Prehist., 73, N. ${ }^{\circ}$ 1, enero-junio 2016, pp. 7-28, ISSN: 0082-5638

doi: $10.3989 /$ tp.2016.12161 


\subsubsection{Sílex tipo 4}

Se le han adscrito hasta 102 elementos del conjunto de útiles retocados y núcleos. La aptitud de talla de este tipo de sílex oscila entre alta y muy alta. La coloración es oscura con tonalidades de gris a negro, aunque también aparecen algunas piezas de tonos marronáceos. El córtex, cuando se conserva $(17,65 \%)$, es de litología caliza y generalmente con escaso rodamiento y un contacto neto con la masa silícea. A la lupa binocular se ha identificado una textura heredada heterogénea con abundantes inclusiones de óxidos metálicos, cuarzo detrítico y cristales romboédricos de calcita o dolomita. El contenido bioclástico es también cuantioso. Está compuesto de espículas de esponja, calciesferas y pequeños foraminíferos, entre los que se han determinado globigerínidos y textuláridos (Fig. 4: T.4). El contenido de inclusiones y bioclastos determina un origen marino para este sílex tipo 4.

Al microscopio petrográfico, presentan un mosaico de microcriptocuarzo como textura principal, siendo la única forma de la sílice observada. En porcentajes reducidos se documentan componentes carbonatados (micrita y componentes esqueléticos, éstos en proceso de silicificación). Los óxidos son abundantes, de morfología granular y distribuidos en toda la lámina. No aparecen porosidades ni tampoco cementaciones. Espículas de esponja y secciones de globigerínidos son el principal contenido micropaleontológico observado al microscopio petrográfico (Fig. 5: T.4).

El sílex tipo 4 posee paralelos con los sílex de la Formación Agua-Salenz, que aflora al sur del macizo del Turbón, así como su equivalente lateral, la Formación Pardina, que aflora en la cuenca de Sopeira (Caus et al. 1993, 1997; IGME 2009). Los afloramientos más cercanos al yacimiento de Montlleó se encontrarían a $110 \mathrm{~km}$ en línea recta hacia el oeste. Estos serían accesibles descendiendo por el río Segre y remontando por el Noguera Ribagorzana o bien cruzando las elevaciones montañosas que conectan los valles del Segre, el Noguera Pallaresa y el Noguera Ribagorzana hasta llegar al valle del Lierp, donde junto al afloramiento primario y subprimario fue localizado un taller de sílex ${ }^{4}$ (Fig. 6).

\footnotetext{
${ }^{4}$ Sánchez, M. 2015: Las sociedades cazadoras-recolectoras del Paleolitico superior final pirenaico: territorios económicos
}

A nivel mineralógico (Tab. 4), la muestra analizada del sílex tipo 4 tiene similitudes con la perteneciente a la Formación Agua-Salenz, pese a observarse en ambas algunas diferencias. Así, el sílex tipo 4 está constituido por un $97 \%$ de cuarzo y un 3\% de calcita. En cambio, la muestra geológica posee un $94 \%$ de cuarzo, un $5 \%$ de calcita y un $1 \%$ de dolomita.

\subsubsection{Sílex tipo 5}

Se le han asignado 10 piezas $(0,84 \%$ del total), caracterizadas por una coloración marronácea clara, pero con una alta opacidad. La aptitud para la talla de este tipo de sílex es alta. El córtex, conservado en un $30 \%$ de las piezas, es de litología caliza y presenta evidencias de rodamiento. A la lupa binocular se identifica una textura heredada heterogénea compuesta por inclusiones de óxidos y grandes foraminíferos, entre los que es posible discernir secciones de alveolinas y assilinas (Fig. 4: T.5). Se ha determinado un origen marino para este tipo de sílex por su contenido micropaleontológico.

La escasez de restos, sumado al hecho de que mayoritariamente son tipos primarios, ha imposibilitado la elaboración de láminas delgadas para una caracterización microscópica de estos elementos. A escala macroscópica este tipo no tiene paralelos con los sílex estudiados de ambas vertientes de la cordillera pirenaica. Estamos, por tanto, ante un aporte puntual que llega al yacimiento fruto quizás de un intercambio entre grupos.

\subsubsection{Sílex tipo 6}

Se le han atribuido 16 elementos $(1,34 \%$ del material retocado analizado). Es un sílex de aptitud entre media y baja para la talla, pues se observan con frecuencia fisuras, de origen tectónico. Son sílex de coloraciones oscuras dentro de la gama de los negros. Solo una pieza conserva el córtex, sin signos de rodamiento y de litología caliza margosa con un contacto difuso

y sociales. Tesis doctoral inédita. Universidad de Barcelona. Barcelona. 
con la masa silícea. La textura heredada es heterogénea con inclusiones de óxidos, abundantes relictos carbonatados y cristales romboédricos de calcita o dolomita en proceso de disolución (Fig. 4: T.6). Ha sido posible identificar algunas secciones bioclásticas, cuya determinación no ha sido factible.

La escasez de restos atribuibles a este tipo de sílex y sus dimensiones ha impedido elaborar láminas delgadas. No obstante, las particulares características que presenta nos han permitido relacionarlo con los sílex de la Formación Corones, que emergen a lo largo de la Sierra del Cadí y cuyos afloramientos localizados más próximos al yacimiento de Montlleó se sitúan a tan solo 11 $\mathrm{km}$ al SO del mismo, en la parte alta de la Sierra del Cadí (afloramiento del Comabona) o en las faldas de ésta (afloramiento de Riugréixer) (IGME 1994; Calvet et al. 2007) (Fig. 6). Así, pese a ser afloramientos localizados en lo que se considera un radio de aprovisionamiento local (inferior a $10 \mathrm{~km}$ ), cabe tener en cuenta que para acceder a ellos se debe solventar la Sierra del Cadí, con elevaciones superiores a los $2.000 \mathrm{~m}$.

\subsubsection{Jaspes}

Hasta 14 piezas retocadas fueron elaboradas sobre jaspe. Se trata de una silicificación de aptitud media para la talla con un lustre algo brillante. El elevado contenido en inclusiones de óxidos metálicos confiere a las piezas una coloración fundamentalmente rojiza y anaranjada (Fig. 4: T.7). Se trata de una silicificación muy opaca, por lo que la determinación textural macroscópica resulta complicada.

La observación al microscopio petrográfico de las láminas delgadas de algunos jaspes recuperados en Montlleó ha permitido identificar una textura heredada en la que el componente mayoritario no es la sílice sino los óxidos metálicos (Fig. 5: T.7). Integran los componentes silíceos un mosaico de microcriptocuarzo y en proporciones más reducidas cristales de megacuarzo subeuhedrales dispuestos en mosaico en el relleno de antiguas porosidades. Los componentes carbonatados previos a la silicificación también existen y siempre son no esqueléticos (micrita). Se ha observado una porosidad intergranular de tipo primario.
Esta variedad jaspeada tiene sus paralelos en una silicificación de radiolaritas conocidas en el sinclinal de Vilafranca de Conflent, junto al macizo del Canigó. Afloran en posición secundaria en las terrazas del río Têt, a la altura de Vinça, en forma de grandes bloques rodados $\mathrm{y}$, en menores cantidades, desde Millas hasta Canet en Rosellón ${ }^{5}$ (Fig. 6). A escala macroscópica y microscópica las características de los jaspes del Canigó son idénticas a las observadas en los ejemplares de Montlleó, por lo que podríamos estar ante una aportación de sílex extra-regional en la que los afloramientos más cercanos se situarían a más de $60 \mathrm{~km}$ del yacimiento.

\subsection{Relación de datos tras la caracterización arqueopetrológica}

El análisis arqueopetrológico de la industria lítica retocada de Montlleó ha aportado otras características de interés que exponemos a continuación. Se refieren a la presencia de córtex, las alteraciones o el peso y al modo como afectan o se presentan en cada uno de los seis tipos de sílex diferenciados.

El córtex puede ser un importante indicador del tipo de gestión del material y de la litología de la formación encajante. Si obviamos el tipo 5 (solo 10 piezas), el tipo 2 presenta el porcentaje cortical más elevado 25\% (Fig. 7). Mayoritariamente son córtex marginales $(19,35 \%)$. Por el contrario, los menores porcentajes corticales (86\% de No Corticalidad) corresponden a los sílex de tipo 3. Los porcentajes de No Corticalidad de los tipos 1 y 4 superan el $82 \%$.

Estos bajos porcentajes corticales son habituales en útiles retocados y núcleos. La presencia reducida de córtex es un indicador de la llegada al yacimiento tanto de nódulos parcialmente desbastados y de pequeñas dimensiones como de soportes ya configurados. Este dato concuerda perfectamente con los resultados del estudio tecnológico de una parte del material retocado de

\footnotetext{
${ }^{5}$ Grégoire, S. 2000: Origine des matières premières des industries lithiques du Paléolithique pyrénéen et méditerranéen. Contribution à la connaissance des aires de circulations humaines. Tesis doctoral inédita. Universidad de Perpignan. Perpignan. Véase p. 120.
} 


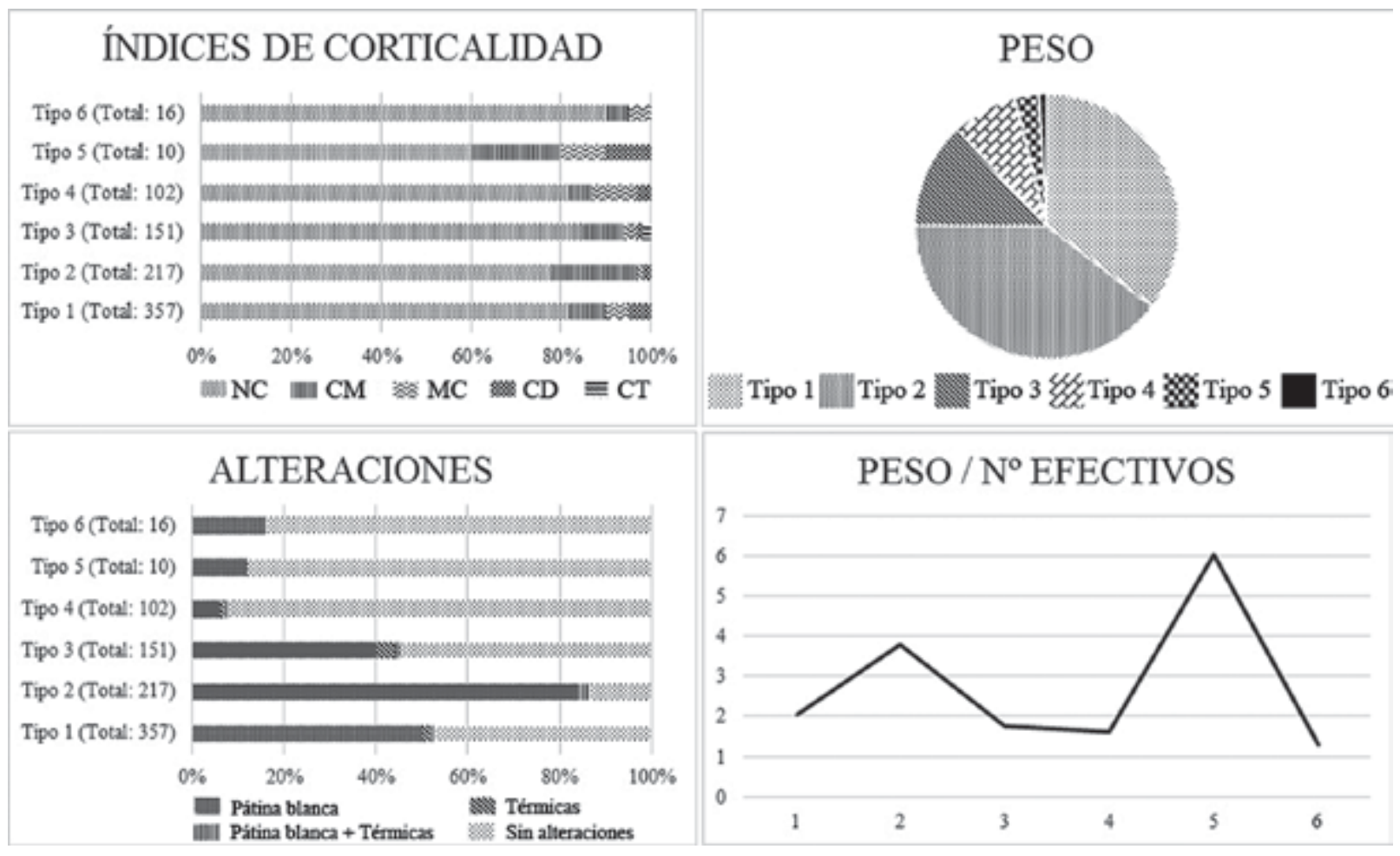

Fig. 7. Montlleó, tipos de sílex identificados en la industria lítica retocada. En la parte superior, porcentajes corticales: NC No Cortical; CM Córtex Marginal; MC Medianamente Cortical; CD Córtex Dominante; CT Córtex Total. En el centro, principales alteraciones observadas. En la parte inferior, representación porcentual del valor real del peso para cada tipo.

Langlais (2010), donde dio a conocer diversas cadenas operativas líticas para la configuración del utillaje retocado. Las láminas llegarían ya talladas al sitio, y sería en el yacimiento donde se producirían las laminitas a partir de núcleos de tamaño reducido (Langlais 2010). Además, si tenemos en cuenta que las distancias de las fuentes de abastecimiento al yacimiento superan los $100 \mathrm{~km}$ (salvo las del tipo 6) el material llegaría mayormente como núcleos ya configurados. Los primeros estadios de la cadena operativa lítica (decorticado y primera configuración del soporte) se habrían realizado previamente en otro lugar.

Las principales alteraciones determinadas tras el análisis macroscópico del material han sido la pátina blanca y las de carácter térmico, ambas dependientes del tipo de sílex (Fig. 7). Por lo general el conjunto lítico está bastante alterado, lo que podría relacionarse con el tipo de asentamiento, al aire libre, y con procesos fundamentalmente postdeposicionales.

La pátina blanca es la alteración más frecuente y oscila entre el 74,20\% (tipo 2) y el 5,88\% (tipo 4).
Los porcentajes en los tipos 1 y 3 son del 49,02\% y el 39,73\% respectivamente. La diferencia de afectación entre tipos podría estar en relación con la mayor o menor porosidad de las silicificaciones. Los sílex del tipo 2, originados en una facies sedimentaria de tipo continental lacustre evaporítica, poseen texturas más gruesas y algunas fisuras relacionables con una mayor porosidad, comportando una mayor alteración por pátina blanca. En cambio, los sílex del tipo 4, con unas superficies lisas y homogéneas, serían menos porosos.

Las alteraciones térmicas afectan a los tipos 1,2, 3 y 4 con porcentajes que oscilan, en cambio, entre el 1 y el 3\% en función del tipo de sílex. Las principales son las cúpulas térmicas y los craquelados.

El peso sirve de indicador de la cantidad de material aportado al yacimiento y, por tanto, es un elemento importante en el estudio arqueopetrológico. El conjunto de 853 piezas de sílex que han podido ser adscritas a uno de los 6 tipos pesaba $2,072 \mathrm{~kg}$. Al distribuirlo entre tipos, destacan el 1 (733 g - 35,35\% del peso del conjunto) y el 2 ( 825 g - 39,79\%). El tipo 3 representa el 12,87\% del 
total $(267 \mathrm{~g})$, el tipo 4 el 8,08\% (167 g), el tipo 5 el 2,91\% (60 g) y el tipo 6 el 1\% (21 g) (Fig. 7).

Al dividir el peso de cada tipo de sílex por el total de sus respectivos elementos se han obtenido resultados bastante homogéneos (Fig. 7), comprendidos entre 1 y $3 \mathrm{~g}$. El tipo 2 poseería un peso teórico por efectivo más alto $(3,80 \mathrm{~g})$, posiblemente por tratarse de un tipo de sílex de peor calidad que llega al yacimiento en forma de soportes de dimensiones mayores y cuyos núcleos no se llegan a agotar. Le siguen los tipos 1, (2,05 g), 3 (1,77 g), $4(1,64 \mathrm{~g})$ y $6(1,29 \mathrm{~g})$. Los resultados del tipo $5(6,02 \mathrm{~g})$ con solo 10 efectivos no pueden tenerse en cuenta. De todo ello se desprende que las estrategias de gestión empleadas en los diferentes tipos de sílex explotados en el yacimiento fueron similares y destinadas, por lo general, a obtener soportes de dimensiones reducidas.

\subsection{Relación entre tipos de sílex y análisis tecno-tipológico}

Con el objetivo de conocer mejor las estrategias de explotación de recursos empleadas en los diferentes tipos de sílex explotados hemos relacionado los datos con los del análisis tecno-tipo- lógico previo (Laplace 1974), efectuado durante las campañas de excavación. Junto a similitudes entre tipos de sílex existen también ciertas diferencias interesantes (Fig. 8). En los sílex lacustres del tipo 1 observamos el predominio marcado de los elementos de retoque abrupto (52\%). El segundo grupo son los núcleos $(24 \%)$ y los elementos de retoque simple $(20 \%)$, seguidos por buriles $(1,4 \%)$, écaillés $(0,3 \%)$ y foliáceos $(0,3 \%)$. Hay pocos $(2 \%)$ útiles dobles (perforadores, raederas $\mathrm{y}$ raspadores-buril fundamentalmente).

Los elementos de retoque abrupto también son mayoritarios (34\%) en los sílex continentales lacustres evaporíticos de tipo 2 pero están mucho más igualados con los núcleos $(33,6 \%)$. Los útiles de retoque simple $(22 \%)$, los écaillés $(6 \%)$ y los buriles $(3 \%)$ completan el conjunto.

En los sílex del tipo 3, los útiles de retoque abrupto son mayoritarios $(51,6 \%)$. Los núcleos $(24,5 \%)$ y los elementos de retoque simple $(20,5 \%)$ forman un segundo grupo, seguido a distancia por buriles $(2 \%)$, écaillés $(0,7 \%)$ y útiles dobles $(0,7 \%)$.

Los sílex marinos del tipo 4 se emplean, sobre todo, para elementos de retoque abrupto (54\%) y, en segundo lugar, para núcleos $(29 \%)$. Les siguen los elementos de retoque simple $(12 \%) \mathrm{y}$, finalmente, contados écaillés $(3 \%)$, buriles $(1 \%)$ y útiles dobles $(1 \%)$.

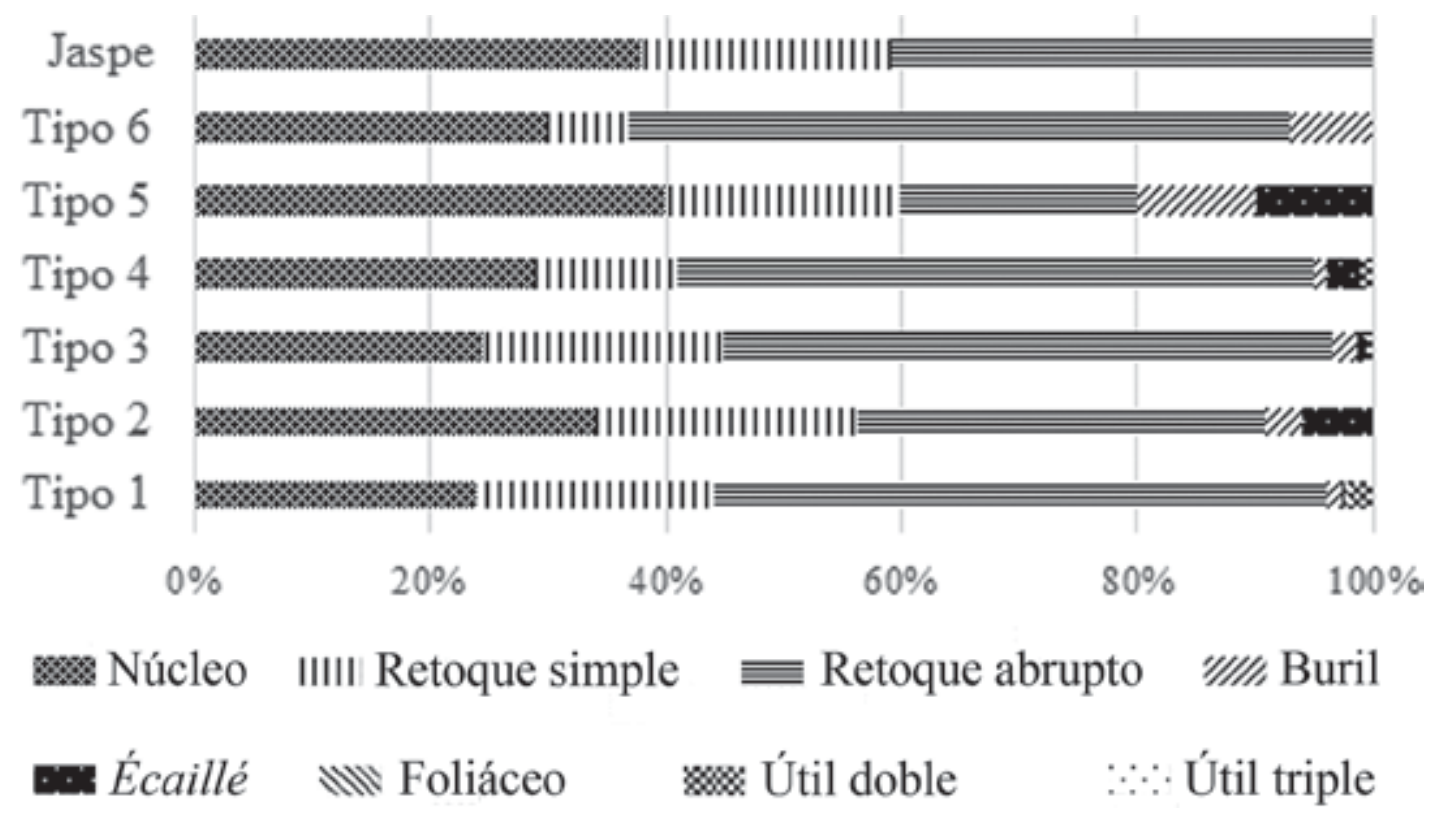

Fig. 8. Clasificación tipológica de los elementos retocados de Montlleó en función del tipo de sílex.

Trab. Prehist., 73, N. ${ }^{\circ}$ 1, enero-junio 2016, pp. 7-28, ISSN: 0082-5638

doi: $10.3989 /$ tp.2016.12161 
La escasez de materiales en los tipos 5, 6 y jaspes (algunos núcleos, elementos de retoque abrupto, de retoque simple y ciertos buriles) nos hace pensar que estamos ante aportes puntuales de núcleos previamente configurados y trabajados in situ.

\subsection{Análisis de una muestra aleatoria de material no retocado}

Los resultados de relacionar el estudio arqueopetrológico del material retocado sobre rocas sedimentarias silíceas con sus correspondientes datos tecno-tipológicos se han completado con el análisis de una muestra aleatoria de un $10 \%$ del no retocado. Para llevar a cabo esa selección se volcó todo el material en una base de datos de Microsoft Excel a la que aplicamos la fórmula de selección aleatoria. La base constaba de algo más de 10.000 piezas, una vez excluidas las procedentes de recogidas superficiales y caídas de corte. De ella escogimos al azar 1.033 piezas $(10,33 \%)$ procedentes de diferentes cuadros y cotas.

Identificamos 1.020 elementos de sílex $(98,74 \%), 9$ jaspes $(0,87 \%)$ y 4 liditas $(0,39 \%)$. En la caracterización macroscópica se han hallado diferentes tipos de sílex, cuya determinación no ha sido posible $(29,52 \%)$ o que se correspondían con los tipos de sílex definidos previamente en el conjunto retocado. Un total de 291 elementos $(28,17 \%)$ se vinculan al sílex lacustre del tipo 1 , el grupo mayoritario en la muestra seleccionada. Hay 267 piezas $(25,85 \%)$ de sílex evaporíticos del tipo 2. Los sílex marinos del tipo 3 son 88 piezas $(8,52 \%)$, los del tipo 4 son $68(6,58 \%)$ y solo hay una del tipo 5 (0,10\%) (Fig. 9).

El estudio arqueopetrológico de la muestra de material no retocado pone de manifiesto la inexistencia de otras silicificaciones en el conjunto. Es decir, las estrategias de gestión y aprovechamiento de los distintos tipos de sílex son similares a las identificadas en los tipos primarios previamente analizados.

\section{DISCUSIÓN}

El estudio arqueopetrológico del conjunto de Montlleó aporta nuevos datos que complementan
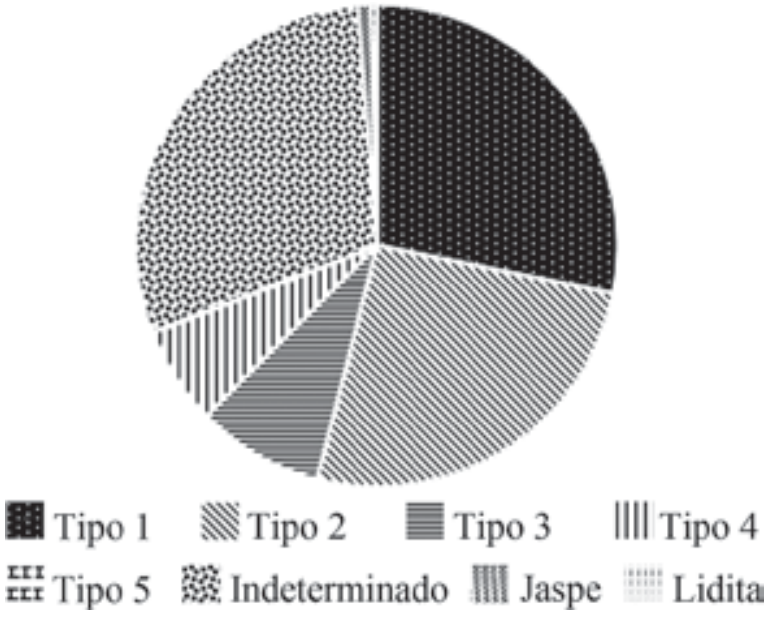

Fig. 9. Adscripción de la muestra de no retocados de Montlleó a los diferentes grupos identificados.

el conocimiento que hasta el momento teníamos sobre las estrategias de gestión y captación de recursos líticos de las comunidades de cazadoresrecolectores que, al fin del Paleolítico superior, se asentaron en el Pirineo centro-oriental. El análisis nos ha permitido diferenciar la aportación al yacimiento de seis tipos de sílex y una variedad jaspeada cuyos orígenes son variados y fundamentalmente exógenos (Fig. 6).

El tipo 1, integrado por sílex formados en una facies sedimentaria continental lacustre, presenta paralelos con diversas formaciones geológicas situadas en un radio de unos $100 \mathrm{~km}$ de Montlleó. En estos momentos no es posible precisar de entre las formaciones posibles cuáles fueron explotadas por los grupos humanos que se asentaron en Montlleó, pues enfrentamos un problema de convergencia de facies silíceas. Es decir, estamos ante sílex de formaciones distintas $\mathrm{y}$, en este caso, lejanas geográficamente, cuyas características similares a la lupa binocular y al microscopio petrográfico son indiferenciables en esta escala de análisis. Sea como fuere y como los rasgos de los sílex del tipo 1 no son ni mucho menos uniformes, debemos pensar que pudo explotarse más de una de las formaciones analizadas. No obstante, entre las cinco formaciones lacustres susceptibles de haber sido explotadas, las correspondientes a los sílex del Oligoceno de Corbières y del Rupeliense de la Serra Llarga, y su extensión al Este y Oeste, pese a su falta de homogeneidad a nivel mineralógico, parecen asemejarse más entre sí a la lupa binocular 
y al microscopio petrográfico que las otras tres formaciones. Ambas formaciones se localizan en un radio superior a los $100 \mathrm{~km}$ del yacimiento en sentidos opuestos. Al nordeste los sílex oligocenos de Corbières serían fácilmente accesibles cruzando el paso de la Percha y siguiendo el eje del río Têt. Al suroeste los sílex rupelienses de la Serra Llarga, se podrían alcanzar siguiendo el curso del río Segre por las sierras prepirenaicas hasta el contacto con la Cuenca del Ebro.

Posiblemente la lejanía de las fuentes de aprovisionamiento explica que este tipo de sílex llegara a Montlleó como soportes preconfigurados y pequeños núcleos que fueron trabajados in situ. Sin embargo su importancia numérica en el registro arqueológico y su uso para elaborar todo tipo de útiles nos inclina a pensar que fuera un sílex recurrentemente explotado. Es de suponer que las fuentes de aprovisionamiento se encontraran en un territorio frecuentado reiteradamente para permitir la adquisición de un material que de manera habitual aparece en el registro arqueológico.

El tipo 2 posee paralelos directos con los sílex del Paleoceno que afloran fundamentalmente en los Petites Pyrénées, y cuyos afloramientos más cercanos se encuentran a $100 \mathrm{~km}$ al noroeste del yacimiento, a tenor de la idéntica composición mineralógica obtenida por Difracción de Rayos $\mathrm{X}$. Es, por tanto, un sílex exógeno que, sin embargo, llega al yacimiento en cantidad durante toda la secuencia estratigráfica. Por ese motivo podemos precisar que estamos ante un tipo de sílex recurrente, que llegaría fundamentalmente como soportes y módulos ya configurados. En Montlleó se desarrollarían los últimos estadios de la cadena operativa lítica para la obtención de laminitas. La gran cantidad de material asociado a esta variedad silícea en un indicador de que las fuentes de aprovisionamiento se encontraban en un territorio frecuentado de manera recurrente, en el que el acceso a los recursos fue accesible si no permanentemente, la mayor parte del tiempo.

Los paralelos geológicos del tipo 3, se han identificado en los sílex maastrichtienses de Montsaunès y en los sílex del Flysch del Cretácico superior que afloran próximos a las localidades de Hibarette y Montgaillard. Ambas formaciones, localizadas en el Pirineo francés, son depósitos en posición primaria y subprimaria junto a los que aparecen talleres de sílex frecuentemente utilizados durante la Prehistoria (Barragué et al. 2001).
Estos afloramientos se sitúan a poco más de 200 $\mathrm{km}$ al noroeste del yacimiento de Montlleó. La mayor lejanía de estos sílex junto a su continuada presencia en el registro arqueológico sin cambios aparentes, ni en la estratigrafía ni en su uso, nos lleva a pensar que estamos ante un aporte recurrente de material pero en menores cantidades. Ello podría relacionarse con una menor frecuentación de ese territorio por los grupos de cazadoresrecolectores que se asentaron en Montlleó.

Se ha establecido una relación directa entre el tipo 4 y una formación geológica localizada en el Pirineo y Prepirineo aragonés. Es la formación Agua-Salenz, que aflora en el valle del Lierp, al sur del macizo del Turbón, y que más al Este aflora de nuevo con nódulos de sílex bajo el nombre de Formación Pardina. Los sílex de ambas formaciones presentan idénticas características. Los afloramientos de la Formación Pardina están algo más próximos al yacimiento de Montlleó pero en estos momentos nos inclinamos por la explotación de los sílex de la Formación Agua-Salenz en sus afloramientos del valle del Lierp. La razón principal es el hallazgo de restos de talla pertenecientes a un antiguo taller junto al depósito primario de sílex. Además, en los afloramientos que a día de hoy se conocen de la Formación Pardina en la Cuenca de Sopeira, el sílex aparece altamente encajado y su extracción es difícil. Igualmente, los últimos trabajos de prospección en la zona parecen indicar que no hay afloramientos de este tipo de sílex más al este de la cuenca de Sopeira. Sea como fuere, ambas formaciones y los afloramientos que hoy se conocen (valle del Lierp y cuenca de Sopeira) están a más de $120 \mathrm{~km}$ de distancia del yacimiento, siendo por tanto sílex exógenos.

En el registro arqueológico los sílex del tipo 4 se distribuyen a lo largo de la secuencia estratigráfica para elaborar utillaje diverso. No obstante, más del $50 \%$ del sílex de este tipo sirvió para la confección de elementos de dorso (actividades cinegéticas), posiblemente debido a la alta aptitud para la talla que generalmente presenta. Llama la atención el reducido porcentaje de núcleos, muy inferior al del resto de variedades silíceas. Parece que el sílex llega al yacimiento en forma de soportes y módulos ya configurados, realizándose actividades de talla in situ pero con menos frecuencia que las efectuadas con los tipos 1, 2 y 3 . Los sílex del tipo 4 son aportados recurrentemente pues aparecen de manera continuada en la estratigrafía del yacimien-

Trab. Prehist., 73, N. ${ }^{\circ}$ 1, enero-junio 2016, pp. 7-28, ISSN: 0082-5638

doi: $10.3989 /$ tp.2016.12161 
to. Como ya se ha apuntado para el caso anterior, su menor cantidad puede explicarse por ubicarse en un territorio menos frecuentado por los grupos humanos que se asentaron en Montlleó.

A día de hoy no se conocen las fuentes de aprovisionamiento del único elemento no retocado del tipo 5, pues no presenta paralelos con las formaciones estudiadas al sur y norte de los Pirineos. Pensamos que es un aporte puntual, posible fruto de un intercambio entre grupos y cuyo origen haya que buscar en radios mucho más alejados a los que aquí se plantean.

Los sílex del tipo 6 se relacionan con los sílex de la Formación Corones, que aflora a lo largo del Pirineo centro-oriental y en las proximidades del yacimiento, en la Sierra del Cadí. Sus afloramientos más cercanos se sitúan a tan sólo $11 \mathrm{~km}$ de Montlleó, pero su aparición entre el conjunto retocado y en la muestra aleatoria es testimonial. Esto puede deberse a varias razones. Estamos ante un sílex cuya aptitud para la talla es mediocre por la alta tectonización de los nódulos, por lo que su explotación resulta dificultosa. Además, si bien la cercanía de los afloramientos permitiría definirlo como un sílex local, para llegar a ellos es necesario cruzar la Sierra del Cadí, con elevaciones que superan fácilmente $\operatorname{los} 2.000 \mathrm{~m}$.

La hipótesis que planteamos en este momento sobre el abastecimiento del tipo 6 es que su explotación fuera puntual, quizás expeditiva. Pudo llegar algún nódulo de sílex a alguno de los cauces que desde el Cadí bajan al río Segre, y posteriormente ser recolectado en posición secundaria por los grupos humanos, que a su vez se abastecieron de otras litologías locales (liditas, cuarzo, cuarcitas y riolitas). Como segunda hipótesis planteamos que, buscando un paso alternativo para llegar al Sur, se cruzara la Sierra del Cadí por alguno de los pasos naturales e históricos (p.ej. el Pas dels Gosolans, que conecta el valle de la Cerdaña con el valle de Gósol) donde afloran sílex de la Formación Corones. En este caso hay que valorar también el clima severo que acompañó a los grupos magdalenienses de Montlleó, cuando muchos de estos pasos (por encima de $2.000 \mathrm{~m}$ ) estarían bloqueados por la nieve y el hielo gran parte del año.

Finalmente, la variedad definida como jaspeada, escasamente representada en el registro arqueológico analizado, tiene paralelos directos con los denominados Jaspes del Canigó, una silicificación hidrotermal que aflora junto al maci- zo del Canigó y que está en posición secundaria en las terrazas del río Têt. Los afloramientos de esta variedad jaspeada se hallarían a algo más de $70 \mathrm{~km}$ al este del yacimiento y serían fácilmente accesibles siguiendo el eje del río Têt al cruzar el paso de la Percha. La escasa aparición de esta silicificación en el registro arqueológico debería relacionarse con sus superficies rugosas y su baja aptitud para la talla. Llegaría al yacimiento de manera puntual fruto quizás de una recogida en un depósito secundario en el transcurso de un desplazamiento para otro tipo de actividad (¿cinegética?) aprovechado para una talla ocasional.

\section{CONCLUSIONES}

La localización en el mapa de Montlleó y de las diferentes zonas de captación de recursos líticos susceptibles de haber sido explotados muestra el yacimiento está "en una zona de paso". Esa expresión no debe considerarse sinónima de ocupación puntual del territorio. Montlleó es un asentamiento ocupado en diversos momentos durante un mismo periodo cronocultural y seguramente (como muestran las dataciones obtenidas por C14) por sucesivas generaciones. Sin embargo, las características propias del yacimiento y los fenómenos postdeposicionales han conllevado la formación de un único nivel arqueológico, que se presenta uniforme y sin vacíos ocupacionales en su desarrollo vertical, asociado a una tipología lítica que concuerda con las dataciones absolutas obtenidas, que lo adscriben al Magdaleniense inferior.

La ubicación del yacimiento es clave para hacer hincapié en la idea de que está en zona de paso. Sobre un pequeño montículo en el valle de la Cerdaña, Montlleó se sitúa en uno de los lugares más accesibles para cruzar la Cordillera Pirenaica, con suaves elevaciones que permiten, siguiendo los ejes de los ríos Têt y Segre, solventar las elevadas cumbres que rodean la comarca para conectar con otros valles próximos. La identificación de las zonas de procedencia de las materias primas líticas nos informa o sobre la zona de procedencia de los grupos humanos que se asentaron en el yacimiento, o sobre por dónde y con qué frecuencia transitaban por el territorio en sus recorridos. El peso de los tipos de sílex identificados, el tipo de útiles elaborados en cada 
uno de ellos, así como el número de núcleos es significativo a ese respecto. No obstante, debido a la convergencia de facies silíceas que presentan una parte de los materiales, no somos capaces de determinar -en el actual estado de nuestros conocimientos- los sentidos generales de las marchas.

La circunstancia citada no excluye el gran valor para la interpretación arqueológica de haber hallado evidencias de jaspes del Canigó, de sílex del Flysch del Cretácico y de sílex Bleu del Paleoceno entre el material arqueológico de Montlleó, pues son indicadores seguros de una de las direcciones tomadas por estos grupos humanos. Del mismo modo, desde el paso de la Percha se accede al valle del Têt y fácilmente es posible alcanzar la zona de Corbières y así explotar el sílex lacustre que tanto abunda en el registro arqueológico. $\mathrm{Si}$ cruzado el paso de la Percha, se toma el valle del Querol, en pocos kilómetros se alcanza la región del Ariège, donde se ubican importantes yacimientos arqueológicos con niveles magdalenienses, donde están presentes el sílex Bleu del Paleoceno y el sílex del Cretácico superior que aparecen en el registro de Montlleó. Se manifiesta así una tradición cultural en el empleo de estas variedades mantenida durante el Magdaleniense.

Hacia el Sur, la explotación de los sílex de la Formación Agua-Salenz (tipo 4) pone de manifiesto la existencia de un contacto al sur del macizo pirenaico y hasta el Pirineo central, fácilmente accesible siguiendo las elevaciones que conectan los ríos Segre y Nogueras. Al descender por el valle del Segre estos grupos humanos pudieron explotar los recursos silíceos que ofrecían las formaciones del Rupeliense (tipo 1) y conectar con estas primeras sierras prepirenaicas, donde también ha quedado en evidencia la tradición de una ocupación desde el Magdaleniense inferior al superior final. Montlleó podría ser el primer referente cronocultural de un comportamiento de movilidad territorial por el río Segre que se desarrolla a lo largo de todo el Magdaleniense.

La escasa aparición de sílex de la Formación Corones entre el material arqueológico del sitio debe entenderse como un indicador de que, si bien puntualmente pudo cruzarse la Sierra del Cadí para enlazar con el curso del río Llobregat, éste no fue ni el trayecto principal ni el habitual de los grupos que se asentaron en Montlleó.

El estudio arqueopetrológico de Montlleó prueba el contacto entre ambas vertientes del Pirineo ya en el Magdaleniense inferior. La aparición en el registro arqueológico de material con esa procedencia es con seguridad el ejemplo más claro que podamos poseer de la ausencia de barreras orográficas y culturales al fin del Paleolítico superior en el Pirineo centro-oriental. La falta de barreras bien podría extenderse a la totalidad de la Cordillera Pirenaica y a lo largo del Paleolítico superior, según ponen de manifiesto los recientes estudios arqueopetrológicos de Tarriño y Elorrieta (2012) que, para el Gravetiense de Alkerdi (Urdax, Navarra) y el Auriñaciense y Gravetiense de Aitzbiarte III (Landarbaso, País Vasco), identificaron sílex de tipo Chalosse, cuyas fuentes de aprovisionamiento se ubican en la vertiente norpirenaica. El análisis de otros complementarios, como los desarrollados por Langlais (2010) sobre aspectos tecnoeconómicos de la industria lítica de numerosos yacimientos magdalenienses del ámbito pirenaico, entre los que se incluyen materiales de Montlleó, pone de manifiesto la existencia de una homogeneidad tecno-tipológica en el Pirineo centro-oriental al fin del Paleolítico superior (Langlais 2010).

Sin duda alguna, el estudio intensivo de la composición elemental de los distintos tipos de sílex explotados en Montlleó y sus posibles áreas de captación, sobre el que trabajaremos próximamente, se entrevé como prometedor. Éste análisis, unido a la revisión de estudios arqueopetrológicos de yacimientos de similar cronología del ámbito pirenaico, permitirá una mejor comprensión de las estrategias de aprovisionamiento y gestión de los recursos líticos empleadas por los grupos humanos que al fin del Paleolítico superior se asentaron en el Pirineo centro-oriental.

\section{AGRADECIMIENTOS}

Esta publicación ha sido posible gracias a un contrato predoctoral FPU del Ministerio de Educación, Cultura y Deporte del que M. Sánchez es beneficiaria. El trabajo se inscribe en los proyectos HAR 2011-26193 del Ministerio de Ciencia e Innovación y SGR 2014-108 de la Generalitat de Catalunya, dirigidos por el Dr. Josep Maria Fullola, al que agradecemos su apoyo. Asimismo agradecemos los comentarios de los evaluadores anónimos, que han enriquecido el trabajo.

Trab. Prehist., 73, N. ${ }^{\circ}$ 1, enero-junio 2016, pp. 7-28, ISSN: 0082-5638

doi: $10.3989 /$ tp.2016.12161 


\section{BIBLIOGRAFÍA}

Anadón, P.; Cabrera, L.; Colldeforns, B. y Sáez, A. 1989: "Los sistemas lacustres del Eoceno superior y Oligoceno del sector oriental de la Cuenca del Ebro". Acta Geológica Hispánica 24(3-4): 205-230.

Barragué, J.; Barragué, E.; Jarry, M.; Foucher, P. y Simonnet, R. 2001: "Le silex du Flysch de Montgaillard et son exploitation sur les ateliers du Paléolithique supérieur à Hibarette (Hautes-Pyrénées)". Paléo 13: 29-51.

Bilotte, M. y Andreu, B. 2006: "Les marnes d'Auzas (Maastrichtien supérieur sous-pyrénéen). Stratigraphie et paléoenvironnements, association d'ostracodes". Revista española de Micropaleontología 38: 309-320.

Bressy, C. 2003: Caractérisation et gestion du silex des sites mésolithiques et néolithiques du nord-ouest de l'arc alpin. Une approche pétrographique et géochimique. British Archaeological Reports, International Series 1114, Archaeopress. Oxford.

Briois, F. 2005: Les industries de pierre taillée néolithiques en Languedoc Occidental. Monographies d'Archéologie Meditérrannéenne 20. Lattes.

Calvet, F.; Playà, E.; Giménez-Montsant, J. y Permanyer, A. 2007: "Fifth-order cyclicity and organic matter contents relationship (Lower Eocene, Pyrenees)". Geologica Acta 5 (1): 59-75.

Caus, E.; Gómez-Garrido, A.; Simó, A. y Soriano, K. 1993: "Cenomanian-Turonian

platform to basin integrated stratigraphy in the South Pyrenees (Spain)". Cretaceous Research 14: 531551.

Caus, E.; Teixell, A. y Bernaus, J. M. 1997: “Depositional model of a Cenomanian-Turonian extensional basin (Sopeira Basin, NE Spain): interplay between tectonics, eustasy and biological productivity". Palaeogeography, Palaeoclimatology, Palaeoecology 129: 23-36.

Chung, F. H. 1974: "Quantitative interpretation of $\mathrm{X}$-Ray diffraction patterns of mixtures. I. Matrix -flushing method of quantitative multicomponent analysis". Journal of Applied Crystallography 8 (1): 17-19.

Fullola, J. M.; Mangado, X.; Tejero, J. M.; Petit, M.A.; Bergadà, M. M.; Nadal, J.; García-Argüelles, P.; Bartrolí, R. y Mercadal, O. 2012: "The Magdalenian in Catalonia". Quaternary International 272273: 55-74.

Gauthier, G.; Burke, A. L. y Leclerc, M. 2012: "Assessing XRF for the geochemical characterization of radiolarian chert artifacts from northeastern North America". Journal of Archaeological Science 39 (7): 2436-2451.

Gomis, E.; Parés, J. M. y Cabrera, L. 1997: "Nuevos datos magnetoestratigráficos del tránsito Oligoceno-Mioceno en el sector SE de la Cuenca del Ebro (provincias de Lleida, Zaragoza y Huesca, NE de España)”. Acta Geológica Hispánica 32 (3-4): 185-199.

Hassler, E. R.; Swihart, G. H.; Dye, D. H. y Li, Y. S. 2013: "Non-destructive provenance study of chert using infrared reflectance spectroscopy". Journal of Archaeological Science 40 (4): 2001-2006.

IGC 2008: Àger. Mapa Geològic de Catalunya 1:25.000. Institut Geològic de Catalunya e Institut Cartogràfic de Catalunya. Barcelona.

IGC 2010: Atles Geològic de Catalunya 1:50.000. Institut Geològic de Catalunya y Institut Cartogràfic de Catalunya. Barcelona.

IGME 1994: La Pobla de Lillet: Mapa Geológico de España. Escala 1:50.000. Hoja 255. Instituto Geológico y Minero de España, Ministerio de Industria. Madrid.

IGME 1995: Puigcerdà: Mapa Geológico de España. Escala 1:50.000. Hoja 217. Instituto Geológico y Minero de España, Ministerio de Industria. Madrid.

IGME 1998: Balaguer: Mapa Geológico de España. Escala 1:50.000. Hoja 359. Instituto Geológico y Minero de España, Ministerio de Industria. Madrid.

IGME 1999: Monzón: Mapa Geológico de España. Escala 1:50.000. Hoja 326. Instituto Geológico y Minero de España, Ministerio de Industria. Madrid.

IGME 2006: Os de Balaguer: Mapa Geológico de España. Escala 1:50.000. Hoja 327. Instituto Geológico y Minero de España, Ministerio de Industria. Madrid.

IGME 2009: El Pont de Suert: Mapa Geológico de España. Escala 1:50.000. Hoja 213. Instituto Geológico y Minero de España Ministerio de Industria. Madrid.

Langlais, M. 2010: Les sociétés magdaléniennes de l'Isthme pyrénéen. Comité des travaux historiques et scientifiques, Collection Documents Préhistoriques 26. Paris.

Laplace, G. 1974: "La typologie analytique et structurale: base rationnelle d'étude des industries lithiques et osseuses". En M. Borillo y J.C. Gardin (eds.): Banques de données archéeologiques. Colloques Nationaux du CNRS. París: 91-143.

Mangado, X. 2005: La caracterización y el aprovisionamiento de los recursos abióticos en la Prehistoria de Cataluña: las materias primas silíceas del Paleolítico Superior Final y el Epipaleolítico. British Archaeological Reports, International Series 1420, Archaeopress. Oxford.

Mangado, X.; Fullola, J. M. y Mercadal, O. 2015: "Montlleó i les evidències de les ocupacions paleolítiques a Cerdanya: un abans i un després en la recerca". En J. Gallart (ed.): Primeres jornades d'Arqueologia i Paleontologia del Pirineu i Aran (Coll de Nargó 2013): 88-95. Lleida.

Mangado, X.; Mercadal, O.; Bergadà, M.M.; Nadal, J.; Langlais, M.; Tejero, J. M.; Esteve, X.; Medina, B.; Rodríguez, N.; Grimao, J. y Fullola, J. M. 2011: 
"Montlleó (Prats i Sansor, Cerdanya). Balanç de 10 campanyes d'excavació". Tribuna d'Arqueologia 2009-2010: 27-52.

Mangado, X.; Tejero, J.M.; Fullola, J.M.; Petit, M.A.; García-Argüelles, P.; García, M.; Soler, N. y Vaquero, M. 2010: "Nuevos territorios, nuevos grafismos: una visión del Paleolítico superior en Catalunya a inicios del s. XXI”. En X. Mangado (ed.): El Paleolítico superior peninsular. Novedades del siglo XXI. Homenaje al Profesor Javier Fortea. Monografías del Seminari d'Estudis i Recerques Prehistòriques 8. Barcelona: 63-83.

Mangado, X.; Tejero, J.M.; Fullola, J.M.; Petit, M.A. y Sánchez, M. 2014: "La cova del Parco (Alòs de Balaguer, La Noguera, Lleida). La secuencia magdaleniense". En R. Sala (ed.): Los cazadores recolectores del Pleistoceno y del Holoceno en Iberia y el estrecho de Gibraltar. Estado actual del conocimiento del registro arqueológico. Universidad de Burgos y Fundación Atapuerca. Burgos: 152-158.

Montes, L. y Domingo, R. (ed.) 2013: El asentamiento magdaleniense de Cova Alonsé (Estadilla, Huesca). Monografías Arqueológicas, Prehistoria 48, Universidad de Zaragoza. Zaragoza.

Mora, R.; Benito-Calvo, A., Martínez-Moreno, J.; Torre, I. de la; Vega, S.; Roy, M.; Roda, X. y Samper, S. 2014: "Una secuencia clave en la Prehistoria del Mediterráneo Occidental: Cova Gran de Santa Linya (Prepirineo de Lleida)". En R. Sala (ed.): Los cazadores recolectores del Pleistoceno y del Holoceno en Iberia y el estrecho de Gibraltar. Estado actual del conocimiento del registro arqueológico. Universidad de Burgos y Fundación Atapuerca. Burgos: 162-166.

Olivares, M.; Tarriño, A.; Murelaga, X.; Baceta, J. I.; Castro, K. y Etxebarría, N. 2009: "Non-destructive spectrometry methods to study the distribution of archaeological and geological chert samples". Spectrochimica Acta Part A. Molecular and Biomolecular Spectroscopy 73: 492-497.

Parish, R. M.; Swihart, G. H. y Li, Y.S. 2013: "Evaluating Fourier Transform Infrared Spectroscopy as a non-destructive chert sourcing technique". Geoarchaeology - An International Journal 28 (3): 289-307.

Roy, M.; Tarriño, A.; Benito-Calvo, A.; Mora, R. y Martínez-Moreno, J. 2013: “Aprovisionamiento de sílex en el Prepirineo oriental durante el Paleolítico superior antiguo: el nivel arqueológico 497C de Cova Gran (Santa Linya, Lleida)". Trabajos de Prehistoria 70 (1): 7-27.

Séronie-Vivien, M.; Séronie-Vivien, M.R. y Foucher, P. 2006 : "L'économie du silex au Paléolithique supérieur dans le bassin d'Aquitaine. Le cas des silex à lépidorbitoïdes des Pyrénées centrales. Caractérisation et implications". Paléo 18: 193-216.

Simonnet, R. 1999: "De la Géologie à la Préhistoire: le silex des Prépyrénées. Résultats et réflexions sur les perspectives et les limites de l'étude des matières premières lithiques". Paléo $11: 78-88$.

Soler, N. 1976: La Bora Gran d'en Carreres. El paleolitic a les comarques gironines. Servei d'Investigacions Arqueològiques. Girona.

Soto, M.; Gómez, B.; Vallverdú, J. y Vaquero, M. 2014: "Potential siliceous sources during Prehistory: results of prospecting in the East margin of the Ebro Basin (NE Iberian Peninsula)". Journal of Lithic Studies 1: 293-318.

Speer, C.A. 2014: "LA-ICP-MS analysis of Clovis period projectile points from the Gault site". Journal of Archaeological Science 52: 1-11. 38

Tarriño, A. 2006: El sílex en la Cuenca Vasco-Cantábrica y Pirineo navarro: caracterización y su aprovechamiento en la Prehistoria. Monografía del Museo Nacional y Centro de Investigaciones de Altamira 21, Ministerio de Cultura. Madrid.

Tarriño A. y Elorrieta, I. 2012: "La explotación de los recursos abióticos durante el Gravetiense cantábrico. Primeros datos sobre el Pirineo occidental y la cuenca vasco-cantábrica". En C. de las Heras, J.A. Lasheras, A. Arrizabalaga y M. de la Rasilla (eds.): Pensando el Gravetiense: nuevos datos para la región cantábrica en su contexto peninsular y pirenaico. Actas del Coloquio Internacional Gravetiense cantábrico. Monografía del Museo Nacional y Centro de Investigaciones de Altamira 23. Ministerio de Educación, Cultura y Deportes. Madrid: 330-346.

Ullastre, J. y Masriera, A. 1999: “Análisis estratigráfico del Paleógeno del sinclinal de Tragó de Noguera: su importancia en la geología regional (Pirineo catalano-aragonés, España)". Treballs del Museu de Geologia de Barcelona 8: 85-111.

Utrilla, P.; Baldellou, V.; Bea, M.; Montes, L. y Viñas, R. 2014: "La cueva de la Fuente del Trucho (Asque - Colungo, Huesca)". En R. Sala (ed.): Los cazadores recolectores del Pleistoceno y del Holoceno en Iberia y el estrecho de Gibraltar. Estado actual del conocimiento del registro arqueológico, Universidad de Burgos y Fundación Atapuerca. Burgos: 171-178.

Utrilla, P. y Mazo, C. (ed.) 2014: La Peña de las Forcas (Graus, Huesca). Un asentamiento estratégico en la confluencia del Ésera y el Isábena. Monografías Arqueológicas, Prehistoria 46, Universidad de Zaragoza. Zaragoza.

Utrilla, P.; Montes, L.; Mazo, C.; Alday, A.; Rodanés, J.M.; Blasco, M.F.; Domingo, R. y Bea, M. 2010: "El Paleolítico superior en la cuenca del Ebro a principios del siglo XXI. Revisión y novedades". En X. Mangado (ed.): El Paleolítico superior peninsular. Novedades del siglo XXI. Homenaje al Profesor Javier Fortea. Monografías del Seminari d'Estudis i Recerques Prehistòriques 8. Barcelona: 23-62.

Vera, J.A. 2004: Geología de España. Instituto Geológico y Minero de España. Madrid.

Trab. Prehist., 73, N. ${ }^{\circ}$ 1, enero-junio 2016, pp. 7-28, ISSN: 0082-5638

doi: $10.3989 /$ tp.2016.12161 